\title{
Project Putin-2024 in the Geostrategy of Confrontation and Internal Challenges
}

\author{
Dr . Eugene Alexander Vertlieb
}

"The new world order will be built against Russia, on the ruins of Russia, and at the expense of Russia." (Zbigniew Brzezinski)

\section{Introduction}

$\mathrm{F}$ ranklin Delano Roosevelt left us with the notion that we cannot do without Russia. But in the post-war world, a tough approach to Russia has prevailed, one based on Sir Winston Churchill's Fulton concept: there can be only a total and uncompromising struggle of the "countries of freedom" against "tyranny." And you need to have an overwhelming superiority in military power that ensures a "mutual understanding with Russia."' "More aggression" against Russia and China these days harkens back to naval commander Admiral John Richardson. ${ }^{2}$ Balancing on the edge of a razor blade is like balancing on the edge of a collapse into war. But sometimes actions speak louder than words. In the harsh confrontation with the Democratic People's Republic of Korea, the militant rhetoric of the Americans did not match their scrupulous observance of the "red line" clearly drawn by Pyongyang.

Since a balance of power is the general principle for equilibrium in modern international relations, then conducting wars is justified by concerns over establishing that "balance" or "equilibrium." With the collapse of the USSR, the balance of mutually-deterrent forces ended and the temptation arose to strike with impunity the weakened, ontological enemy. "The old doctrine of the balance of power is no longer applicable. We cannot afford," Churchill declared in 1946, "to act from a position of small advantage which tempts us to engage in a test of strength." And China no longer adheres to its former nuclear doctrine of "minimum deterrence." Testing the forces and means of the enemy, right up to the point of reconnaissance in force, is becoming a

1 Former British prime minister Winston Churchill delivered what is known as the "Fulton Speech" or "Iron Curtain Speech" in Fulton, Missouri, on March 5, 1946. In the speech, he stressed the necessity for the United States and Britain to act as the guardians of peace and stability against the menace of Soviet communism.

2 ohn Michael Richardson is a retired four-star admiral in the United States Navy who previously served as the 31st Chief of Naval Operations. Admiral Richardson has called for taking more of a hardline approach with Russia and China in the wake of incidents challenging the US navy with dangerous and aggressive flying and sailing actions. See (2019, February 7) Navy chief says the US needs to hit first and get 'muscular' with Russian and Chinese ships. Business Insider. URL https://www.businessinsider.com/chief-naval-officer-richardson-us-navy-go-onoffensive-against-russian-chinese-ships-2019-2. 
daily norm in the relationship between the opposing sides. "I'm not going to ask my commanders to take the first blow on the jaw," recently said Commander of US Naval Forces in Europe and Africa Admiral Robert Burke. And what about the precedent of granting impunity for the Pristina march of Russian paratroopers? ${ }^{3}$ So then it is hardly likely that NATO ships in the territorial waters of the Russian Federation will open fire to destroy Russian ships. For nuclear blackmail, the Russian Federation has the "Shkval" torpedo, capable, as is reported in the media, of changing the military balance - "and conquering the whole world."

The West won the Cold War, but it is losing the Cold Peace. The victors were led astray by their own arrogance and the false belief that the rival center of power had been done away with forever. Frederick the Great warned on this score: "It is easier to kill the Russians off than it is to achieve victory over them." It was a huge strategic mistake to let pass the favorable moment for the complete "binding" of Russia to the West at a time when it was ready for it. In the operational language of the military, "H-Hour" was lost.

Russia, hovering on the brink of non-existence, was able not only to endure, but also to successfully compete with the West in hypersonic and space-based weapons - and future conflicts will be resolved in space. The growing strength and resurging aspirations of the Russian Federation became evident in the fighting rhetoric of $\mathrm{V}$. Putin: "Even if we had sunk this ship, the world would not have wound up on the verge of a world war," the president said about the incident with the British destroyer "Defender." ${ }^{5}$ And China's usually evasive political narrative suddenly became undiplomatically harsh: "The Chinese people will absolutely not allow any foreign force to bully, oppress or enslave us and anyone who attempts to do so will face broken heads and bloodshed in front of the iron Great Wall of the 1.4 billion Chinese people," said Xi in a speech during a 1 July 2021 celebration of the 100th anniversary of the Chinese Communist Party's founding. ${ }^{6}$

3 "Russia’s surprise deployment of 200 troops to the Pristina airport on June 12 was part of a scheme to send into Kosovo a contingent of 1,000 or more men who could have tried to stake out a Russian zone in the northwest sector of the province, Western intelligence analysts have concluded." See (1999, June 25) Secret Russian Troop Deployment Thwarted. Washington Post. Page A1. URL https://www.washingtonpost.com/wp-srv/inatl/longterm/balkans/stories/russians062599.htm.

4 The Battle of Zorndorf was fought during the Seven Years' War between Russian troops and the Prussian army commanded by King Frederick the Great. The battle was tactically inconclusive, with both armies holding their ground and claiming victory.

5 In June 2021, 'HMS Defender,' sailing from Odessa to Georgia, passed south of the Crimea peninsula, which Russia annexed from Ukraine in 2014. While Moscow claims the peninsula and its waters are Russian territory, the UK says HMS Defender was passing through Ukrainian waters in a commonly used and internationally recognized transit route. See (2021, June 23) HMS Defender: Russian jets and ships shadow British warship. BBC News Services. URL https://www.bbc.com/news/world-europe-57583363.

6 (2021, July 1) Xi Jinping Says Foreign Forces Will “Face Broken heads and Bloodshed" if They Bully 
The Chinese are almost doubling their nuclear potential. By investing in strengthening its nuclear power, China is pursuing several goals at once: improving nuclear capabilities, conventional forces, and missile defense. Their DF- 41 missiles are capable of striking targets at a distance of more than 14,000 kilometers. With an abundance of dummy missile silos, it is difficult to know where the real complexes are - the ones with hypersonic gliding winged elements or interceptor missiles for anti-missile or anti-satellite defense that are hidden away, protected from the first strike. Together with the Russian weapons "Zircon," "Poseidon," "Sarmat," "Dagger," and "Peresvet," the arsenal is impressive. ' In terms used by Eurasianist P. N. Savitsky in $1959,{ }^{8}$ this "breaks the very horn of Western pride at its very root." The end of the bipolar world order is comparable in effect to a natural cataclysm - as if there was a fracture in the earth's crust, then the North American and Eurasian tec- tonic plates diverged, and giant rifts appeared. And now the unipolar American domination no longer suits the Russian Federation or the PRC, but the United States is hindering the formation of a multipolar world, viewing it as a threat to its national security. China, the third in terms of nuclear power, is adopting the concept of a retaliatory strike, similar to the Russian one.

Anti-Russian sanctions and restrictions have proved to be ineffective. And more than that: While the US economy just about stalled - up to $15 \%$ of the world's economy (approximately as was the USSR's position under Gorbachev), and American monetary assets became not all that stable (experiencing liquidity risks and excess cash), Russia has managed to build up its gold reserves and together with the PRC, withdraw their national currencies from the dollar "risk zone." And the press is incessantly talking about not only the processes that are disintegrating in Russia, but also about whether the Unit-

\footnotetext{
China. Newsweek. URL https://www.newsweek.com/xi-jinping-says-foreign-forces-will-face-broken-heads-bloodshed-if-they-bully-china-1605984. According to various press sources, there has been confusion over the translation of the statement made by Chinese President Xi Jinping at a ceremony marking the centenary of the ruling Communist Party in Beijing, China. See (2021, July 2) Did Xi Jinping Threaten to Bash Enemies' Heads Or Was It Lost In Translation?" Vice World News. URL https://www.vice.com/en/article/3aq5qy/china-speech-xi-jinping-ccp-metaphor.
}

7 The SARMAT (Russian: CAPMAT) is a liquid-fueled, MiRV-equipped super-heavy ICBM; ZIRCON (Russian: ЦИРКОН) refers to a hypersonic anti-ship missile; POSEIDON (Russian: ПОСЕЙДОН) is an autonomous, nuclear-powered, nuclear-armed unmanned underwater vehicle; DAGGER (Russian: КИНЖАЛ) is a nuclear-capable, air-launched ballistic missile; and, PERESVET (Russian: ПЕPECBET) is a combat laser system apparently designed to damage the optical systems of drones, cruise missiles, or satellites.

8 Nicolas, G., Seriot, P., Lavroukhin, V., and Vullioud, V. (1998, January) Russia-Eurasia according to Savitsky. [Abstract]. Research Gate. URL https://www.researchgate.net/publication/298446006_ Russia-Eurasia_according_to_Savitsky. According to the report's abstract, "Petr Nikolaevich Savitsky (1895-1968) was...the first to propose, during and after World War I, a geopolitical vision of 'Eurasia', an entity which, according to its advocates, is neither Europe nor Asia, but a 'place for the development' of the Russian Empire and the USSR, the successor of the Mongol Empire." 
ed States of America will dissolve into 51 independent governments - if the District of Columbia is given the status of statehood.

Russia is still considered to be an "Upper Volta with missiles." President Joe Biden just updated the description: he characterized the country that ranks eighth in the size of its economy as merely one that "has nuclear weapons and oil wells, and nothing else. Nothing else." "Objectively speaking, Russia is a country that is growing weak in economic and demographic terms," said the head of British intelligence MI6, Richard Moore. And with such an awful demographic curve like that of the Russian Federation, the country should be thinking about just surviving. And the ruling oligarchy in no way serves as a stimulus for the people to work and achieve. As the Reichsleiter of Propaganda Joseph Goebbels rightly said, "Guns and bayonets are nothing if you do not possess the hearts of a nation."

The toolkit of Western influence on Russia is unchanging: the alternating of "the carrot and the stick" - engaging with Russia or levying sanctions on it. However, the former libertarian image of the Russian Federation, which flared up in the "dashing 90s" and quickly faded, has never reappeared. And it is unlikely that this specter of false hopes — frightening-to-Russians - will ever reappear again. After all, the "point of no return" for that dogma has passed. Yet the West is not receptive to the new world order that is emerging; it continues to squeeze Russia which cannot be squeezed anymore and acts as the lone arbitrator in serious international disputes regardless of the consensus of other opinions. Judging by the response made by the press secretary of the Russian Federation President, Dmitry Peskov, to the aforementioned statement by Joe Biden, "there is a false knowledge and understanding of modern Russia." This is a miscalculation of Western systems analytics. Indeed, the inaccurate understanding of the true political and psychological state of the USSR, and the underestimation of the resilience of the Russian will to survive cost Imperial Minister of Foreign Affairs Joachim von Ribbentrop a trip to the gallows. Russia is far from being a "colossus with feet of clay" or "just a gas station country." When it comes to spiritual strength, it seems to me, it is the Western dominion that is a kind of symbiosis of sub-colony and sub-empire. Russia should not be underestimated.

As Alexander Solzhenitsyn pointed out in his article "Misconceptions About Russia Are a Threat to America," ${ }^{\prime}$ the manipulation of facts about Russia has left "the entire West in a critical and even deadly position." It is absurd to accuse Russia of every mortal sin, including the origin of totalitarianism. After all, it was not "Emperor Nicholas I" who came up with the idea of totalitarianism, as Richard Pipes contends. The idea of a

9 Solzhenitsyn, Aleksandr. (Spring 1980). Misconceptions about Russia are a Threat to America. Foreign Affairs, Vol. 58 (Number 4), p. 15. URL https://www.foreignaffairs.com/articles/russia-fsu/19 80-03-01/misconceptions-about-russia-are-threat-america. 
totalitarian state was first proposed by Hobbes in Leviathan ${ }^{10}$ - the head of state is the master not only over property and life, but also over the conscience of its citizens. Yes, and Rousseau as well laid the groundwork for this, declaring that a democratic state is "a sovereign with no limits not only over property, but also over the identity of its citizens." As the Russian proverb says, "Don't blame the mirror if the face is crooked."

It is a losing proposition for Russia when it winds up being a "pawn" in other's games, and when it makes its decisions and seeks the approval of both the collective West (the "New Entente") and China. For Russia, the task to restore its original worldview and geopolitical "code" is first-priority, the "code" being the set of key views held by the Russian people about their place in history and in the world, their foreign policy strategy, and their national priorities. They should do as the Chinese in politics: without fail, in all agreements, the Chinese require "duiden" - parity in relations, measures, and steps. In accordance with the spiritual concept of "yin and yang" ("chaos and order"), they require a ranking of the entities involved - and an end to any chaotic activity.

Russia is aiming to get out of isolation and renew competition among the three world systems. It is preparing for an asymmetric, non-contact war to achieve political goals without any open military hostilities. It is developing the skills needed for net-based cyber warfare, especially against communications and logistics systems as well as developing the ability to counter attacks by the "fifth column" - including sabotage and subversion - and attacks on its financial infrastructure and information operating systems. It tries to keep its gunpowder dry - to be on the alert and ready for anything. After all, the rhetoric of war is growing more and more deafening. On 24 January 2021, the Kremlin said quite emphatically that Moscow was not ready to be dictated to or to put up with rudeness. "You need to play honestly with the Russians or not at all" - words passed down to us by the "Iron Chancellor" Otto von Bismarck. ${ }^{11}$

The strategies and tactics for influencing enemies and opponents often look unreliable. Thus, simultaneously pressuring Russia and China is hardly advisable since it is not very effective, but instead contributes to the consolidation of these "outcasts." And with regard to Minsk, the radical tactics of promoting democracy by any means, up to a coup détat, have turned out to be a losing proposition. As a result of this false start - either an inaccurate gauging of the current situation or an underestimation of the subjective aspects of the case - the plan to change

10 Hobbs, T. (1651) The Matter, Forme and Power of a Commonwealth Ecclesiasticall and Civil. Commonly called Leviathan, the work concerns the structure of society and legitimate government, and is regarded as one of the earliest and most influential examples of social contract theory.

11 Otto von Bismarck served as prime minister of Prussia (1862-73, 1873-90) and founder and first chancellor of the German Empire (1871-90). 
the regime collapsed, which has only accelerated the integration of Belarus into Russia’s camp. And judging by Vladimir Putin's article "On the historical unity of Russians and Ukrainians," ${ }^{12}$ the Kremlin has its own views on Ukraine as well. The increasingly frequent blunders in its strategic planning and in the implementation of its schemes confirm that its mega-project for unifying non-Western civilizations to universalize common values - an "axiological sterilization" - has noticeably been faltering. In systems analytics, such flaws can be fatal.

But these that have been cited as well as other Western miscalculations - in Syria, Iran, and Afghanistan are matched by the Russian inability (or unwillingness?) to take advantage of the enemy's mistakes. Total corruption in the way it makes decisions is evident by the involvement of its "denationalized elite" and deconsolidated society. "Russia can have as many nuclear suitcases and nuclear buttons as it wants," Zbigniew Brzezinski said sarcastically, "but since $\$ 500$ billion belonging to the Russian elite is in our banks, you still have to decide: is it your elite or is it ours? I do not see a single situation in which Russia would use its nuclear potential." The method of subjugating the state by taming its elite has been known since ancient times. Thus the ancient Greeks, who were panicked by the Scythians, tried to, if not conquer them, then at least safeguard their city states from Scythian attacks by introducing their leaders to Greek culture. However, according to Herodotus, if the Scythian kings even began to embrace Greek customs, their subjects would kill them mercilessly.

President Putin would like to see the Russian people united and monolithic. But the yawning gap between the ruling oligarchy and the poor - the rest of the Russian people - is only splitting all the wider. Clearing the electoral field of candidates unsuitable to the ruling circles confirms the fact that V. Putin or a creature of his making who "suits everyone" - S. K. Shoigu - is being readied for the next presidential term. ${ }^{13}$ In the event of a force majeure, this person could make use of a military dictatorship to intimidate the "the criminally insane" - and "the low-lifes."

So then given that the rate of stabilizing the stagnation cannot be changed, both the internal opposition and the West need to be dealt with. Considering the former, with the growth of the protest movement, we can expect repressive measures to intensify to "establish public order": with the escalation of "unsanctioned activities," "constitutional order must be restored." Some of those fighting for a better fu-

12 Putin, V. (2021, July 12) On the Historical Unity of Russians and Ukrainians. URL http://en.krem lin.ru/events/president/news/66181.

13 On 19 June 2021, Putin announced that his foreign minister and his defense minister - Lavrov and Shoigu, respectively - would head the candidates' list for the dominant United Russia party in September's parliamentary election. See (2021, June 19) Putin names Lavrov, Shoigu to United Russia elections list. APNews. URL https://apnews.com/article/europe-russia-elections-business-govern ment-and-politics-4c84dc1a80eb3b1feac31b0506e0adde. 
ture for Russia would prefer cooperating with the "Putinoids" even while the majority of Russians, cut out from having any dignified sort of life, would be doomed to struggle for existence, to be "marginalized," and to openly oppose the post-Belovezha ${ }^{14}$ T.O.R. - Temporary Occupation Regime. ${ }^{15}$ In this version of Russia's fate, the power that "United Russia" has would most likely be snatched away by the patriots-statesmen of a "united Russian people, that is, the Russian-Ukrainian-Belarusian people." ${ }^{16}$ And the fact cannot be discounted that a small civil war may be needed to open up the post-Belovezha abscess on the body of the Fatherland.

In the cynical language of politics: those supporting a "red-brown" ${ }^{17}$ ideology should not do away with the comprador-oligarchic power (as was done when the Poles were expelled from Moscow in 1612). It would be more pragmatic for the West to stop defaming Putin (after all, he is, deep down, very loyal to Berlin though resented by Washington) and view him as an equal in earnest, and try to truly partner with his entourage if only for beneficial tactical reasons - to let the fly get stuck in amber resin. After all, Russia is unlikely to return to the libertarian model, and if genuine government by the people is unacceptable to the Putinists, they will indeed resist it with all their might. In this sense, they are strategic partners with the West. Therefore, would it not be more expedient for Washington and Brussels - since Berlin and Paris have already done so - to change the paradigm of their relations with Russia - at least to not interfere with Putin's "improvisations" to improve the Russian Federation under the slogan "this is no repeat of 1937 for you!"? ${ }^{18}$ And with such concurrence in positions, there would be no

14 Belovezha refers to the Belovezha Accords signed twenty-five years ago that ended the Soviet Union and established the Commonwealth of Independent States. See (2016, December 7) History in the Making: The Agreement That Ended the Soviet Union. URL https://www.themoscowtimes. com/2016/12/07/history-in-the-making-the-agreement-that-ended-the-soviet-union-a56456.

15 Temporary Occupation Regime is how the Russian people have long referred to the current official power in the Russian Federation. (E.V.)

16 The patriots-statesmen are a mixture of Orthodox socials and national powers. Among them there are those who would like to see a "USSR-2," and achieve the unification of the Russian people, i.e., the Russian-Ukrainians-Belarusians." (E.V.)

17 Melchor, Thorne. (2019, March 28) What is Red-Brownism. [Transcript of Video Segment] URL https://existentialenso.medium.com/what-is-red-brownism-3a67b40fe46 which reads, in part, "One term you may sometimes hear in socialist circles is "red-brownism." In this color scheme, the red refers to socialism, and the brown refers to fascism - the implication being that the ideology bridges fascist and socialist politics. The most overt example of this is a NazBol or National Bolshevik, a movement that originally started essentially as Nazism for people who idolized Stalin instead."

18 "On July 31, 1937, one of the most terrible documents in history was signed: the secret operational order of the NKVD No. 00447, which marked the beginning of the events known as 'Yezhovism, although in all fairness one should speak of Stalinism." N. I. Yezhov was head of the People's Commissariat for Internal Affairs (NKVD) - the secret police - under Stalin. See Krechetnikov, Artem. (2017, July 31) Stalin's Strike: 80 years ago the Great terror started in the USSR. BBC Rus- 
need for "subversive activities" as such. After all, there would be a regime that is the most favorable to the West and one with minimum dividends for Russia. The stratagem here is to not interfere when the tree is falling in the right direction. And no matter how paradoxical it sounds, a "left turn" by moderate specialists and statesmen-patriots makes sense: they can truly consolidate the people and raise the economy (like the Primakov-Maslyukov government), ${ }^{19}$ and become an attractive Eurasian-civilizational core-of-the-Earth power.

\section{The West must adopt a new paradigm}

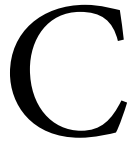

onclusions: Don't interfere with Putin (even as concerns the Russian-German gas pipeline); abandon the Chubais-Navalny "liberal dictatorship" since the project has outlived itself, and invest in a real chance for changing power to a technocratic-patriotic one. After all, it was the most reliable approach for the West to deal with Stalinist predictability and positional clarity. The proposed strategy of establishing business cooperation was first used by Kaiser Germany itself; it helped - at the same time - both the Russian Whites (it did not interfere with them) and the Reds (it strengthened them). The Russian man of St. John does not live by "bread alone" - by rationalism - but, rather, by the spirit.
And the principles of Realpolitik speak to the same approach: divide and conquer; don't put all your eggs in one basket. The Americans have more than once brilliantly demonstrated their strategic, multi-faceted vision for the future of global security: In order to minimize the dire consequences of an impending crisis - the Crash of 1929 - the United States secretly decided to take preventive measures to effect the world order. "To do this, it had to provide assistance to Russia so that, once and for all, it could escape devastation - the consequences of its civil war and it had to help Germany escape from the jaws of the Treaty of Versailles," cited General Yuri Drozdov, the illegal resident $\mathrm{spy}^{20}$.

Even though the Western establishment has to change its attitude towards Russia, the US Congress is still, by its directives, prohibiting Biden (like Trump before him) from improving relations with Russia, including trying to block (unsuccessfully, as it turns out) the presidential right to waive sanctions on the Russian Nord Stream 2 gas pipeline. First and foremost, this is a business project. And how much it will become a "geopolitical weapon" depends largely on the West itself - on how flexible the control of the gas valve will be. The new round of the Cold War, started by Obama, slowed down under Trump in the wake of Macron's message

sian Service, Moscow. Original in Russian: (2017, 31 Июля) Сталинксий удар: 80 лет назад в CССР начался Большой террор». URL https://www.bbc.com/russian/features-40756213.

19 A reference to economic planning in the 1990s involving Prime Minister Yevgeny Primakov and First Deputy Prime Minister Yuri Maslyukov, who also headed the state planning agency.

20 An intelligence officer operating in a foreign country without official cover. 
"Pushing Russia away from Europe is a profound strategic mistake." But sound pragmatism did not prevail.

The positions of the conflicting parties are clear. The United States, by maintaining its global dominant role, prevents the rival center of power from growing any stronger. In Russia, the revival of its national identity calls for a return of its society to its Orthodox roots. The obliteration of these roots causes Christian ideals to fade - ideals that consolidate moral and civilizational values. Society becomes chaotic, fragmented, and spiritually deadened. Consequently, social strata break up into conflicting ethno-confessional communities ${ }^{21}$ subject to massive de-Christianization and dehumanization - godlessness and destruction. Russia is archaically nationalistic while the West operates on a supranational level, and therefore ceases to act in accordance with the ways of traditional societies and the "outdated norms" of international law. Naturally then some incident flares up which affects the relationship between the West and Russia.

The practice by the US Congress of making taboo the very possibility of rapprochement with the Russian Feder- ation is significant. Just as the Russian Empire in its time was killed off by the injection of alien internationalist ideas that destroyed its beliefs, so the spiritual monolith of the United States became unstable when the American establishment, starting in the 1960s, became addicted to the ideology of the Frankfurt School of Neomarxism..$^{22}$ The ruling elite, which had betrayed the then dominant conservative tradition, went crazy. The ideological indoctrination that followed - borrowing Italian Marxist Antonio Gramsci's philosophy of praxis ${ }^{23}$ without first critically evaluating it - has backfired today: That theoretical gobbledegook has wreaked havoc by justifying the split of society into patchwork strata and rallying them around the leftist elites under the slogans of fighting "oppression" and granting unlimited freedom. The Democratic establishment is returning to historical justice for one stratum at the expense of infringing on the rights of another. Traditional American society is being deformed beyond recognition by the inoculation of leftist Trotskyism with an admixture of "Hóng Wèibing-ism" - behavior like the Red Guards during the Chinese cultural revolution ${ }^{24}$ - and by class hatred as in "whoever is not with us is against us."

21 A confessional community is a group of people with similar religious beliefs.

22 The Frankfurt School was a school of social theory and critical philosophy associated with the Institute for Social Research, Goethe University, Frankfurt, 1929. It refers to a group of German-American theorists who developed powerful analyses of the changes in Western capitalist societies that occurred since the classical theory of Marx.

23 Antonio Francesco Gramsci (1891-1937) was an Italian Marxist philosopher, journalist, linguist, writer and politician. He was a founding member and one-time leader of the Communist Party of Italy. He held a humanistic understanding of Marxism, seeing it as a "philosophy of praxis."

24 "Hóng Wèibīng-ism" or "Red Guard-ism" refers to the fanatical mass student-led paramilitary social movement mobilized and guided by Chairman Mao Zedong in 1966-7 during the first phase of 
The United States and Russia have undermined each other, and both superpowers have been undermined by foreign ideologies and are "at the broken trough" ${ }^{25}$ to the delight of hegemonic, communist China!

If diplomacy is the art of the possible, then the US Congress makes it the art of the impossible with Russia. And where diplomacy stops, war begins. Permanent cold confrontation among the parties in conflict is punctuated - approximately once a century - by an outbreak of a hot war, and then by a detente-type of pause - a respite and "re-boot" to reconcile targets and munitions or to acquire them. Congress has indeed become fixated on a state of war "by other means."

Every century there is a largescale war between the West and Russia. In 1612, Minin and Pozharsky expelled the Poles from Moscow. In 1709, Peter the First defeated the Swedish king Charles XII at Poltava. In 1812,
Kutuzov stopped the invasion of Napoleon's armies. In 1914, the First World War began. In 2014, Operation Krymnash ${ }^{26}$ was transformed into a new type of war - a hybrid one.

And in the geopolitical aspect, Eurasian Russia - the Heartland - is an axis of history and a coveted trophy in confrontations. Eurasia, with its Russian core and with China at the "side of the road," has been and remains the most important geostrategic target of adversaries. The fundamental thesis of the British geopolitician Sir Halford Mackinder, underlying military and diplomatic efforts, is whoever controls the Heartland controls the whole world. ${ }^{27}$ There will always be clashes over this core part of the Earth which includes the southern underbelly of Russia (rich in ores and water resources). "British Eurasianism" gained notice in the 18th century through William Jones. ${ }^{28}$ According to Mackinder, the Great Game is the confrontation be-

the Chinese Cultural Revolution. The Guard despised traditional culture and customs and sought to identify and eliminate "revisionists," "monarchists," "traitors," and others who were committing "grave crimes against Marxism."

25 A reference to a line from "The Tale of the Fisherman and the Fish" (1833), a poem by Aleksandr Pushkin. The expression means "to be left with nothing - all hopes have vanished."

26 "Krymnash" is a neologism that came into being in 2014 to refer to operations leading to the annexation of Crimea by the Russian Federation. "Krymnash" is a transliterated word combination which translates to "Crimea-our." Operation Krymnash is, therefore, "Operation Our Crimea.

27 Geopolitical theorist Halford J. Mackinder "developed his heartland theory in response to the 19th century competition between Great Britain and Russia. This contest was characterised in large part by the Great Game played out in Central and South Asia...Mackinder's theory is based on the premise that Eurasia is the global pivot point and whoever controls the Eurasian continent-which he refers to as the world island- can exercise global dominance." See Gilchrist, Mark. (2019, August 12) The Great Game Reinvigorated: Geopolitics, Afghanistan, and the importance of Pakistan. The Strategy Bridge. URL https://thestrategybridge.org/ the-bridge/2019/8/12/the-great-game-reinvigorated-geopolitics-afghanistan-and-the-impor tance-of-pakistan.

28 Sir William Jones was an English Orientalist, jurist, and philologist. While a judge on the high 
tween England and the Russian Empire for control over the Eurasian continent not only in the strategic sense but also to carry out the mission of homogenizing the ethno-cultural distinguishing features. Follower of Mackinder, Zbigniew Brzezinski, in his book, The Grand Chessboard: American Primacy and its Geostrategic Imperatives," focuses on the US geopolitical strategy for Eurasia. In its 2002 National Security Strategy, Americans defined themselves as a Eurasian power and named Eurasia as a priority region of the 21st century.

And the "Gothic civilization" of the Pan-Germanists lays claim to the Black Sea region, and asserts its right for a geopolitical penetration into Asia. But the great von Bismarck warned: "Even the most favorable outcome of the war will never lead to the disintegration of Russia, which is supported by millions of Russian believers of the Greek confession (Orthodoxy). The latter, even if split apart by international treaties, will reunite just as quickly as separated droplets of mercury." Churchill tells us: "Russia cannot be defeated by force; it can be destroyed from within."
The approach used to try to understand the Russian Sphinx is to not see it rationally (as it is), but to view it as an adversary (the way they would like to see it). Therefore, absurd conclusions are drawn such as: "What is good for a Russian, is death for a German." ${ }^{29}$ But these peoples are interconnected, like the German notion of Vaterland and the Slavic deity "Earth Mother." Germanic ethnographers have considered the Slavs to be Aryans; this can be clearly seen on a 19th century map from the Bibliographic Museum in Leipzig. The artifacts of antiquity from the Rhine to the Upper Volga speak to the Slavic-German common "culture of battle axes (or Corded Ware)." ${ }^{30}$ The Teutons have Proto-Slavic genes from the Pomorian, Ruyan, Bodrich, Lyutichi and Lugichan tribes. And according to the "Wielkopolska Chronicle", Germans and Slavs are blood brothers (germo<Latin germanus - bud, seed; having the same parents): where Jan is from the Slavic branch and Kus is from the German branch, and both are sons of Father Yafet. ${ }^{31}$

court of Calcutta, he became a student of ancient India. See Watkin, Owen. (no date) Sir William Jones (1746-1794) and Islamic Studies. [Postgraduate Dissertation coversheet \& feedback form] University of Wales. URL https://repository.uwtsd.ac.uk/id/eprint/346/1/Owen\%20Watkin.pdf.

29 In Russian, «Что русскому здорово, то немцу смерть» or "What is good for a Russian, is death for a German," which is akin to the English language expression "One man's meat is another man's poison" in the sense that nothing of benefit for both parties can be found.

30 Also known as the Battle Axe culture or Single Grave culture, the Corded Ware Culture (c. 3000$2350 \mathrm{BCE}$ ) was known for its use of coarse pottery typically decorated with twisted cord impressions and sometimes with other types of impressions or incisions. It was associated with the diffusion of Proto-Germanic and Proto-Balto-Slavic speakers. Corded Ware Culture. Eupedia. URL https://www.eupedia.com/genetics/corded_ware_culture.shtml.

31 One portion of the work, translated from Latin into English, reads, "Germo is a type of vehicle in which two oxen are yoked together to draw a plough or pull a cart, and so the Germans and the Slavs, having common borders, pull together; there is no people in the world so familiar and friend- 
And yet "East is East, and West is West, and never the twain shall meet," writes the British poet R. Kipling. However, he admits the possibility of an honest dialogue between them, writing: "When two strong men stand face to face though they come from the ends of the earth!" 32

In reality, face-to-face meetings between the leaders of both countries - Russia and the US - have yielded contradictory impressions: Biden did not see the soul in Putin that Bush Jr. saw. $^{33}$ The Chekist, ${ }^{34}$ with the credo of "aligning with the judoka," remains an undeciphered code.

Since "Russia cannot be understood with the mind - intellectually - but know it we must, let us look at what makes it "distinct" from a strategic point of view. Russians, are obviously ethnically, anthropologically and culturally Europeans, yet act and think somehow in a different way. To start with, they are strange in the way that they behave, that is, "with a Byzantine dissenting voice" compared to structured Western rationalists: they invite the Varangians to rule them. Is this not a betrayal of the national elite? Or is it not like the bungling of the "Foolovites"? ${ }^{35}$ However, it is all quite logical: there was a reason to invite "Varangian guests." After all, the Swedes taught the "Rusichi" a lot. And from the standpoint of how Russians think, the act is in keeping with "Russianness" - to stay away from the authorities and be indifferent to whatever holds no interest for them. Kind of like "my house is on the edge - I don't know anything," which emphasizes a person's indifference to a particular situation. But this phrase has a double meaning. The accompanying connotation of the proverb is: "My hut is on the edge, i.e., I meet the enemy

ly to one another as the Slavs and Germans." See Lech, Czech, and Rus. Wikipedia. URL https:// en.wikipedia.org/wiki/Lech,_Czech,_and_Rus.

32 These are the first and last lines, respectively, of Rudyard Kipling's poem, "The Ballad of East and West," published in 1889.

33 Following a June 2001 meeting between President Bush and Vladimir Putin, President Bush reported, "I looked the man in the eye. I found him to be very straightforward and trustworthy. We had a very good dialogue. I was able to get a sense of his soul, a man deeply committed to his country and the best interests of his country." See (2014, March 2) Why Putin Plays Our Presidents for Fools. The Atlantic. URL https://www.theatlantic.com/politics/archive/2014/03/why-putin-playsour-presidents-for-fools/461055/.

34 The All-Russian Extraordinary Commission, or "V.Ch.K." - commonly referred to as "CheKa" - was established in 1917 and was the first of a succession of Soviet secret-police organizations leading up to the Committee for State Security (KGB) in which Putin served. Hence the derogatory reference to him as a member of the secret police. He served for 16 years as a KGB foreign intelligence officer until he resigned in 1991 to pursue politics.

35 This is a reference to the 19th Century satirical novel by Russian author M. Ye. Saltykov-Shchredin, "History of One Town" (История одного города). The work is a farcical history of "Stupid Town" (Russian: Глупов) that follows the lives of "bungling" Russian "StupidTown-ites" (Russian: Глуповцы) for hundreds of years as they endure the violence and lunacy of their tyrannical rulers. 
first." ${ }^{36}$ Regarding the difficulties in understanding Russian allegory in the way Russians talk and act, Churchill, fatalistically, states, "I cannot forecast to you the action of Russia. It is a riddle, wrapped in a mystery, inside an enigma..." ${ }^{37}$

Russia is a symbiosis of Europe and Asia in mental, cultural and geopolitical terms. She is simultaneously the heiress of Byzantium; the keeper of the spiritual light of Christianity; and of the Golden Horde, the baptizer in battle for victory in wars. Two main ethnic components merged in Russia: the Slavic-Celtic and the Scythian-Sarmatian (Iranian). This synthesis formed a special civilization possessing ethnocultural characteristics that distinguish it from both the European as well as the Asian-Buddhist and Asian-Islamic types. Before the arrival of the Eastern Slavs, Iranian tribes of Cimmerians and Scythians lived in the RosKiev-Dnepr triangle. They passed on their Scythian-Sarmatian ethnocultural code and name to the Rusichi. It is likely that the spirit of their warlike ancestors has been resurrected today in the very naming of the formidable intercontinental ballistic missile RS-28 "Sarmat"
- the replacement for the "Voevoda," a modification of the "Satan" which is capable of defeating any missile defense system, reaching its targets over the North or South Pole. Russian Scythians "...have nothing to lose, // And we are not above treachery!" as the poet Aleksandr Blok set down for us on paper. ${ }^{38} \mathrm{~A}$ glimmer of Russian tragic maximalism is on the lips of V. Putin as well when he stated, "Why would we want a world without Russia?" ${ }^{39}$ All or nothing. In the ancient Byzantine source, "Strategikon of Mauritius," it is recorded that the Slavs do not accept slavery - not to any extent "... being freedom-loving, they are in no way inclined either to become slaves or to obey, especially on their own land." Therefore, with these people, either do business with them on an equal footing, or not at all.

If Russia had taken the Novgorod-Nordic route - a Skandoslaviya, a union of Slavs and Scandinavians - as opposed to Kievan Rus, it would have become more European-oriented. In the Viking-Norman theory of the origin of the Russian people, the "multinationality" of $\mathrm{Ru}$ rik is strengthened: there is he and the Scandinavian-Dane (King Rör-

36 "My house is on the edge." (In Russian: «Моя хата с краю.») This refers to a house built at the edge of town, away from the center. Consequently, the owner knows nothing of the goings-on at the center of town - and doesn't really care since he is unaffected. An additional meaning could be that being on the outskirts makes you more vulnerable to attack.

37 Churchill made this remark during a radio broadcast in October 1939.

38 From the poem “The Scythians” (In Russian: «Скифы») by Aleksandr Blok (1880-1921).

39 On 7 March 2018, Putin made remarks about Russia's nuclear strategy pointing out that Russia would only retaliate if its very existence was put at stake, saying, "As a citizen of Russia and the head of the Russian state I must ask myself: Why would we want a world without Russia?” See (2018, March 7) 'Why would we want a world without Russia?' Putin on Moscow's nuclear doctrine. RT. URL https://www.rt.com/news/420715-putin-world-russia-nuclear/. 
ik- Hrorek from Jutland Hedeby-Denmark), the Slavic "falcon" with the generic name Rarog, ${ }^{40}$ and the grandson of the Novgorod Prince Gostomysl (the son of his daughter Umila and a neighboring prince). Russia parted with Europe in the 11th century as a result of the schism of the Ecumenical Church and the separation of Catholics from it. At the same time, Orthodoxy became the basis and core of the Russian mentality; it defined the scale of its values and aspirations. The Russian choice of a Russian-Varangian union became the fundamental basis for the consolidation of the tribes and the formation of the "Russian Land" - the prototype of the Russian Empire, with a Russian God and the Imperial black-yellow-white flag.

Russia has proved itself to be practically unstoppable in wars. That is why its persistent disobedience is tamed from the outside by the "loop of anaconda," ${ }_{41}$ and from the inside, by the "Fifth-Column" churning up the turmoil of social disturbance. The Fifth-Column collaborators-Smerdyakovites $^{42}$ dream of the occupation of Russia by "enlightened countries" and of the return of the Russian Fed- eration to the limits of the "mossy, swampy shores" of the sparsely inhabited North. In Russian political lexicon, such people are called the "rotten intelligentsia." This term passed down from Emperor Alexander III to V. I. Lenin. Soviet leader N. S. Khrushchev called the avant-garde artists "pederasts" for their social and political insignificance. The unprincipled intelligentsia was of no use to the Soviet people or the state since it did not serve the "general proletarian cause." Again, what if that same Nikita Khrushchev were to be evaluated in the context of his actions in Crimea using the scale of Russian "specialness"? Was the transfer of Crimea, together with the city of Sevastopol, to the jurisdiction of Ukraine a betrayal of national interests? Or was it being proactive - giving a start to the "self-dissolution" of the USSR? Or was this an attribute of the generous immensity of the breadth of the Russian soul: "If you want, take any horse, take any tent, take the cherished damask steel-- the sword of our grandfathers!" as in Konchak's aria from the opera "Prince Igor" by A. P. Borodin. Russian kindness turning into an obsessive bout of Nozdrev-ness, Nozdrev being the risk-taking, uncere-

40 In Slavic mythology, the Raróg is a fire demon often depicted as a fiery falcon. Fire is the symbol of purity of conscience and mind.

41 "Today, the West is actively using the arsenal of hybrid war against Russia. Not deciding on a direct military confrontation, the United States and its allies are trying to strangle Russia by other methods, to tighten the Anaconda Loop on its neck. That is how the American Rear Admiral Alfred Mahan called his concept back in 1890." See (2018, April 24) Will Russia break the 'Anaconda loop'? Reporter. URL https://en.topcor.ru/1057-razorvet-li-rossiya-petlyu-anakondy.html.

42 "Smerdyakovshchina" (in Russian: «Смердяковщина») is a word describing the contempt and hatred of primarily Russian citizens for Russia; a kind of Russophobia. Those embracing "Smerdyakovshchina" are "Smerdyakovites." The expression "Smerdyakovshchina" appeared in the 1890s and was associated with Smerdyakov, the hero of F. M. Dostoevsky's novel The Brothers Karamazov, who said, "'I hate the whole of Russia." 
monious, cheeky hero of Gogol's Dead Souls. Hence the trace of Russian-ness in someone else's communist dogma force a person to be happy. And at the same time, Russians themselves know that "you can't force people to like you." Everything is extreme: go right up to the limit - the chasm - and then even lean over to take a look.

The unpatriotic nature of the Russian elite is more than compensated for by the people's love for the Fatherland under any rulers. "The godless split-off from the state" is a disease of the elite that causes the suffering of the people. The thoughtless transplanting on to Russian soil by the Russian intelligentsia of what is alien has muddied the national psyche.

"Rationalistic utopianism - the desire to arrange life according to reason, divorcing it from the objective principles of history, from the organic foundations of social order, and from the life-sustaining sacred values of the people's existence" - led to the 1917 revolution, as scientist P. I. Novgorodtsev believes.

The recipe for healing Russian society, according to Dostoevsky, is to stop being insignificant imitators ("strikers") of Europeanism, liberalism, and socialism, and to return the intel- ligentsia from cosmopolitanism to the realization that they are part of a common root system with the people. In order to gain victorious unity for the nation, the intelligentsia must realize that "it can no longer be divorced and torn away from its people... We can, perhaps, lose battles, but nevertheless we will remain invincible precisely by the unity of our national spirit and the consciousness of the people. ...if we have the will, we cannot be forced to do what we do not want, and there is no power on the whole earth that could make us."

But for a long time, Russia has not managed to stay focused on building a state. In 1913, when it ranked first in the world in terms of industrial production growth and fourth in terms of its volume, the First World War, which broke out and turned into the Bolshevik Revolution, destroyed the Russian Empire itself. As concerns the USSR, the 1991 Belovezha Accords turned out to be the destructive force for the collapse of the Soviet Union..$^{43}$ Power was seized by a small group of high-ranking officials. The Comprador-Vlasov ${ }^{44}$ regime of victorious "democracy" declared Russia's independence from itself; is this not the realization of the project "Russia without Colonies?" 45 As a result, instead of the mighty Red Empire, we wound up

43 See, for example, (2016, December 7) History in the Making: The Agreement That Ended the Soviet Union. The Moscow Times. URL https://www.themoscowtimes.com/2016/12/07/history-in-themaking-the-agreement-that-ended-the-soviet-union-a56456.

44 The Vlasovites (in Russian: «власовцы») were servicemen of the Russian Liberation Army who fought on the side of the Third Reich against the USSR during World War II. Andrey Vlasov was a Soviet Red Army general who fought in the Battle of Moscow and later was captured attempting to lift the siege of Leningrad. After being captured, he defected to Nazi Germany and headed the Russian Liberation Army.

45 According to an article from Svoboda, a New York-based Ukrainian-language weekly, "Igor Sin- 
with a small, chipped version - the Russian Federation. A tricolor flew up over the Kremlin resembling the colors of the Dutch-"Vlasov-mercantile" flag of the Provisional Government, which had brought about the fall of the state. The Victory Banner was taken down and stored away like a museum mummy (allegedly "because of the fragility of the satin") and kept in a horizontal position. The Reichstag has been defeated and the banner of the winners is gathering dust in the museum! And a "copy" of it has been "decommunistized" the communist aspects of it washed out of its cloth, and, it would seem, washed from the memory of its descendants the emblems washed out of the original - the "Soviet" sickle and hammer and then the remake of the banner used for ceremonial processions.

The President of the Russian Federation is perceived by the ruling elite as a top-notch manager "who does not interfere" with the conduct of business. The totality of fiefdoms belonging to the dominant clans forms a kind of state within a state - a deep-oligarchic state (a "deep state") versus "the Russian Federation." Despite the coronavirus pandemic and the global systemic crisis, the profits of the rich with ties to the Kremlin, according to the Bloomberg Billionaires Index, ${ }^{46}$ grew by $\$ 23.9$ billion in the first quarter of 2021. As they say, "For some - the war, and for others - the mother is dear." ${ }^{47}$

The Yeltsin Constitution of 1993, practically thrown together the night before the referendum, legalized lawlessness. It is clear: Any radical changes in the existing process for controlling the "succession to the throne," including fair democratic elections, would pose a threat to the emerging feudal regime. Therefore, the establishment prefers not to expose its power to the risk of change, adhering to the strategy of "inertial development." Yeltsin's system of steering the country with the help of "checks," "balances," and "castling moves (shuffles)" remains a guide for Putin's "vertical of power." ${ }^{48}$

Vladimir Putin, according to the conservative publicist Mikhail Nazarov,

yavin and Pyotr Boldyrev, two recent Russian immigrants who advocate dissolution of the Soviet empire and the establishment of separate independent slates, are spearheading a new organization called Russia Without Colonies...They contend that the nationality problem in the USSR is the most acute problem and that 'the Russian society has finally grasped the most important truth: that the strategy in the struggle against communism must be a struggle against imperialism.' The organization came into being during a meeting of Americans to Free Captive Nations, an umbrella organization which includes representatives of more than 30 nations of Eastern and Central Europe as well as those comprising the Soviet Union." See (1978, July 23) Russian emigres form new organization. Freedom. URL https://docplayer.net/54947300-Ukrainian-weeny-lukianenko-is-broughtto-trial-new-york-marks-captive-nations-week.html.

46 The Bloomberg Billionaires Index is a daily ranking of the world's richest people.

47 This Russian proverb refers to the fact that "For some, it's war; for others, it's the chance to reap profits." The original Russian is «Кому война, а кому мать родна.»

48 "Vertical of power" refers to the top-down command structure established by Putin during his presidency. 
"in essence did not change anything in the established oligarchic regime; he just moved it out of the realm of the "Great Criminal Revolution"'49 (S. Govorukhin's definition) and into the realm of the superpower criminal stabilization." In this series of "achievements" by the comprador-oligarchy power structure, there is a "betweenthe-two-agreed-upon double "castling move" - Putin-Medvedev and back again. People got used to the "succession-to-the-throne-by-conspiracy": In March 2021, they allowed the nullification of the four previous presidential terms served, giving Vladimir Putin the opportunity to run twice more for the position of head of the government in the elections of 2024 and 2036.

According to political analyst Valery Korovin, the pro-Western elite now "is not standing with Russia; it collaborates with pleasure, and is ready to engage in betrayal, which completely correlates with the situation on the eve of the February Revolution of 1917 when the head of state wound up having no one to rely on. The elite bear a different mentality; it is easy for the West to work with them, which was also characteristic of the pre-revolutionary period." As the poet Maximilian Voloshin said about the events of the 1917 Revolution, "Russia is finished...And the people dragged their homeland// Like carrion to a reeking landfill." ${ }^{50}$

The Red Empire of the USSR was done away with somewhat differently in the "dashing 90s." First, they seized the foundation cornerstone of the Soviet monolith - Article 6 of the 1977 Constitution identifying the party as "the leading and guiding force of society." This immediately brought down the "Indestructible Union." ${ }^{51}$ Now, when the "red-brown" are gathering together for revenge, the ruling parties of Russia have latched on to Putin so that he, their patron, would not cast them out to be torn apart by the crowd. The thought of a departure of V. V. P. (Putin) from the Kremlin and a left-liberal turn by the state elicits a hysterical reaction from liberal-imperialist A. B. Chubais: "God forbid we should see a revolution in Russia. It would be bloodred ...A union of Democrats forming an anti-Putin base would not work.... The slogan 'Down with Putin's Police Regime!' just does not sound serious," he

49 See Govorukhin, S. (1993) The Great Criminal Revolution (in Russian: «Великая криминальная революция»). Andreyevsky Flag Publishers. 126 Pages. ISBN 5856080262. Govorukhin produced a documentary film by the same name. For a brief description, see Douglas, Rachel. (1994, July 15) Documentary film on Russian crime is presented in Washington. Executive Intelligence Review, Vol. 21 (Number 28), pp. 142-145: "Russian film director Stanislav Govorukhin produced a documentary film about the two years following the dissolution of the USSR in 1991...The movie - also a book by Govorukhin - exposes the ex-Communist officials who became Russia's nouveaux riches by getting a leg up on amassing wealth when Gaidar decontrolled prices, as well as the mafia kingpins who became their fellow travelers to billionairehood through extortion rackets."

50 The poem "Peace" (Russian: Мир), written in 1917 by Maksimilian Voloshin, starts with "Russia is finished...." The other two lines that follow are from the second stanza of the poem.

51 A reference to the first line of the Soviet National Anthem, "Indestructible union of free republics Great Rus' has united forever to stand!" 
wails. However, the West this time did not heed the warnings of its own creature. The intrigue surrounding the transfer of power remains. But since the state of international relations smacks of a Cuban Missile Crisis-2, why not take advantage of the situation and give Putinism - as Nazarbayev puts it - a "guiding and directing" eternal life? Indeed, in ancient Rome, if faced with extreme danger from outside or from internal turmoil, with the permission of the Senate, the Consuls appointed a dictator. We are still rather far from a nuclear apocalypse. The West is irritated by the persistence of the loser who was defeated in the Cold War but does not acknowledge himself as such. (And in fact, a Cold War Victory Medal was awarded to the "Honorary German," Mikhail Gorbachev.)

\section{Spiritual and civilizational defense of Russia and Attack of mentality as a factor in complicating conflicts}

more reliable protection you need both control over the distant borders of the Russian Federation and the souls of the Russian people - a defense against decay and "depatriotization." "52 Only with the awareness of their deep national values and goals, and only having learned to act according to their life principles can individuals be well-grounded as proactive people. As for projecting force and ensuring security on the far frontiers, "We are quite far from being able to do that," says analyst Dmitry Evstafiev. We must harness our potential for proactively using force in our economic and political interests before a direct military threat to Russia arises. After all, conflicts are becoming more complicated: mentality itself is already being attacked.

With the help of information-organization weapons, ${ }^{53}$ the spiritual belief system of those being attacked can be altered - subjected to "self-disorganization" and "self-disorientation" for example, the "highly likely" Russian Federation interference in the American presidential elections or the United States' involvement in organizing "color revolutions." ${ }^{44}$ Military expert D.

52 An Anglicized rendition of the Russian word depatriotizatsiya (in Russian: «депатриотизация»). The word here refers to a loss of love for the motherland.

53 "Information weapons are the totality of technical, software, and other special resources, constructively intended for the formation of information effects for the purpose of disrupting information processes." See Thomas, Timothy. (Summer 2020) Information Weapons: Russia’s Nonnuclear Strategic Weapons of Choice. The Cyber Defense Review, Vol. 5 (No. 2), Page 136. [Special Edition: Information Operations/Information Warfare].

54 "Color Revolution" is a term that has been used to describe movements that developed in several countries of the former Soviet Union, People's Republic of China, and the Balkans during the early 2000s. For further information, see, for example, Cordesman, Anthony H. (2014, May 28) Russia and the "Color Revolution": A Russian Military View of a World Destabilized by the US and the West. Center for Strategic and International Studies. URL https://www.csis.org/analysis/ russia-and-"color-revolution". 
Lovtsov, an authority on the reflexive technologies of "orgweapons," claims that by imposing various influences on the enemy, one can make him move in a direction that is favorable to the other side; direct his policy into a strategic impasse; wear down his economy with ineffective (overwhelming) programs; slow down his weapons development; distort the foundations of his national culture; and create a "fifth column" among the intelligentsia that, in every possible way, supports, promotes, and carries out pseudo-reforms, and the like. As a result, an atmosphere of internal political chaos is created within the state which leads to a decrease in its economic, political, and military power, and even to its demise. ${ }^{55}$

By passing through the consciousness of each member of society, a long-term, massive informational and moral-psychological influence campaign of a destructive nature creates a real threat to the existence of that nation by transforming its historically-established culture, fundamental worldview, and ideological attitudes - a change in its internal "orgenvironment," which normally determines the vital activities of the state and its armed forces. A stable maintenance of the enemy's strategic illusion is a condition for victory in a mental-hybrid war. In the context of hybrid warfare, psychological operations are of paramount importance. But how do you carry them out if the target - the psychology of the enemy - is not entirely clear and its vulnerabilities have not been fully identified?

Psych warfare has gone from theoretical innuendo to becoming part of the military's daily routine. Whether it is something fake or something still "a secret with seven seals," a reference to a "Dulles Plan" was made in the newspaper "Soviet Russia" for February 20, 1993. Here is what Metropolitan of St. Petersburg and Ladoga John (Snychev) wrote about it: "Having sowed chaos in Russia," American General Allen Dulles, the head of US political intelligence in Europe who later became director of the CIA in 1945, said "we will imperceptibly replace their values with false ones and make them believe in these false values. How? We will find people who think like we do, our helpmates and allies in Russia itself. Episode after episode and grandiose in its scale, the tragic demise of the most rebellious people on earth will be played out and finally, the irreversible extinction of their identity. From literature and art, for example, we will gradually erase their social essence. We will break artists, discourage them from dealing in images, from delving into the processes that take place within the depths of the masses. Literature, theaters, cinema everything will portray and glorify the most base human feelings. We will in every way support and raise up the so-

55 See Lovtsov, D. (1999) On the Problem of the Organization Weapon (in Russian: O проблеме организационного оружия). Military Thought (Военная мысль), No.1, pp. 34-40. The article explores various organization weapons capable of creating conditions that render the enemy disorganized or disoriented, the purpose being to drive an enemy in a desired direction. 
called creators who will plant and hammer into human consciousness the cult of sex, violence, sadism, and betrayal in short, all immorality." ${ }^{36}$

In current instructional materials on undermining the enemy's combat readiness from within, science fiction has become a reality. The primary evil is "those who rule" Russia like a state corporation - like their own fiefdom. The comprador-masters of the Russian Federation, wittingly or unwittingly, also contribute to the disintegration of the "disciplinary socialization" process that their fellow Russian Federation citizens undergo. After this happens, an individual so processed does not obey the more collective-oriented rules. The French philosopher J. Lipovetsky believes that such a hedonized creature is morally shaky, unstable, weak-willed, has a diminished capability for self-restraint and self-control, and possesses a fragmented consciousness lacking high ideals - as well as a will that requires glamor and consumerism, rest and amusement. Such a subject is civilly and politically insignificant, with an atrophied sense of patriotism - and with no idea what it means to give his life for his homeland.

If the strategist Karl von Clausewitz considers the goal of war to be "to force the enemy to fulfill the German will," then the fortitude of the Russians
- their will to resist and win - has now been greatly undermined. Military theorist Andrei Snesarev noted that "at the epicenter of the problems with trying to understand war is the fundamental law of war: the law of the primacy of the spiritual side in the phenomena of battle." With a flagging fighting spirit, you cannot win. The spirit is like fire: it goes out when not tended to. The Chinese stratagem of achieving victory by destroying the spirit as a pillar of resistance can be described like this: "Pull the firewood out from under the hearth," which means when the opponent is too strong for an open fight, you can win by destroying his support. Having an indestructible spiritual force is a guarantee of victory.

According to the sociologist A. Yanakov, the spiritual resource of the people finds its expression in certain values, ideals, ideas, theories, concepts, programs and slogans, public symbols, views, traditions, habits, and morals, which, as a rule, are based on national values. "Strengthening the spiritual and civilizational arsenal would enhance the fighting readiness of both the army and the military security elements of the state."

If in classical wars the goal is to destroy the enemy's forces, and in modern cyber wars, to destroy the enemy's infrastructure, then the goal of the new

56 The Dulles Plan, or Dulles Doctrine, is part of a conspiracy theory claiming that former CIA chief Allen Dulles developed a plan for United States to destroy the Soviet Union during the Cold War by secretly corrupting its cultural heritage and moral values. Some maintain that the plan first appeared and was ascribed to Allen Dulles in a 1993 book by John Snychev, Metropolitan of St. Petersburg and Ladoga. Others claim the idea seems to have originated in a novel by Anatoly Ivanov entitled Eternal Call, which was popular after the fall of the USSR. See URL https://meduza.io/en/ lion/2015/06/08/russian-court-says-fictional-plot-to-destroy-the-ussr-is-extremist. 
type of war is to destroy the intellectual and emotional consciousness, to change the mental - civilizational - foundation of the enemy's society. "I would call this type of war mental," says Adviser to the Minister of Defense of the Russian Federation Andrei Ilnitsky. And in this mental war, the results of information-hybrid attacks on the enemy's mentality may not manifest themselves immediately, but will do so after a generation, when the course that the evolution of consciousness is taking can no longer be reversed. The transformation of Ukraine from "our fraternal brother" to "a follower of Bandera" ${ }^{77}$ is an example of a methodologically poorly controlled alien influence aimed at changing the spiritual code of the nation. For years, corrupt officials of the Russian Federation condoned the anti-Russian nonsense about the "Ukry" ${ }^{58}$ and then condoned their use as "a sacred sacrifice" in someone else's game. And the fact that Russia did not catch on in time - did not "clean out and close up" the wounds in the relations between Kiev and Moscow, but, rather, allowed a break in their historical commonality - it wound up causing Russia to punish itself. The Kremlin dropped the ball: "I wanted the best possible outcome, but it turned out as it always does." And when self-willed Ukraine was in the throes of the Bandera dance and "he who does not dance is a Moscow-lover" was the prevailing sentiment, it was too late to lend support to save the Yanukovych ${ }^{59}$ regime: anti-Russianness became widespread. The Initiation by Russia of the Minsk Agreements ${ }^{60}$ - and the Russian Federation normally gives up very little

57 "The term banderovtsy (in Russian: «бандеровцы») has played a significant role in political discourse over the course of the Ukrainian crisis. Banderovtsy is the Russian word for "banderites" or followers of Stepan Bandera (1909-1959), leader of the revolutionary faction of the Organization of Ukrainian Nationalists, which, along with its partisan army - the Ukrainian Insurgent Army - strove to eliminate all ethnically non-Ukrainian elements from Ukrainian soil (including Jews, Russians, Poles, Gypsies, etc.) and, for a certain period of time, collaborated with Germans in the hope of achieving this goal." See (2015, January 29) The Success of Russia’s Propaganda: Ukraine’s "Banderovtsy." Cambridge Globalist. URL http://cambridgeglo balist.org/? $\mathrm{p}=573$.

58 Some believe the ancient tribes of the Ukry were the forerunners of the modern-day Ukrainian people. Others use the term in a derisive manner to refer to Ukrainians. "Nonsense" was the English word used to convey the author's use of the word "nashpigovyvaniye" (in Russian: «нашпиговывание») which actually refers to "stuffing" in cooking.

59 Viktor Fedorovych Yanukovych served as the fourth President of Ukraine, from 2010 until he was removed from office in the 2014 Ukrainian Revolution.

60 A peace plan for eastern Ukraine (the Minsk Protocol or Minsk Agreement) was signed in 2014. As fighting continued in 2015, leaders from France, Germany, Ukraine, and Russia agreed to a new ceasefire and a package of measures for the implementation of the Minsk Agreement (the 'Minsk II' agreement). Since then, progress has been limited. (March 2020) Ukraine: The Minsk agreements five years on. At A Glance. See also (2021, February 26) The future of Minsk agreements: pressing for implementation or withdrawing. Ukraine Crisis Media Center. URL https://uacrisis.org/en/ minsk-agreements. The article points out that experts underscore that the Minsk agreements are merely a political accord and are not binding under international law - a sentiment with which Russia disagrees. 
- then saved the Ukrainian Army from certain defeat after Debaltsevo. ${ }^{61}$ And the endless dragging on of the Donbass tragedy is due more to the dividends being reaped by the greedy oligarchy supplying fuel for the tanks of "Independent Ukraine."

If the West had not constantly harassed Putin, then the bosses of the Russian Federation would have turned over the Donbass "in fulfillment of the Minsk Agreements." That would have been a blot on the future perspective of the Russian world, analogous to the 1945 Operation Keelhaul, ${ }^{62}$ when the British, in order to fulfill their Allied obligations to Stalin, used rifle butts to forcibly drive the Cossacks and White émigrés to take a bullet or go to the GULAG. Then, however, when Sir Winston Leonard Churchill himself stood at attention in front of Josif Vissarionovich (Stalin) - let's say even if only out of respect - it was nothing like today, when US President Joe Biden confirmed, with a nod of his head, that his "colleague" from the Russian Federation was a "murderer."
How does one reconcile the need to raise the fighting spirit of what looks like and bears the title of a state-forming nation - the Russian Federation with an environment of a demographic decline in particularly Russians, and a tightening in the enforcement of the punitively-applied, anti-Russian Article 282 of the UKRF (Russian Federation Criminal Code)? ${ }^{63}$ The Russian will - its unbending spirit plus its size with its bold sense of daring versus the dreary dullness of moderation and orderliness. The "offspring" of the Russian free spirit is the limitless, free-spirited Russian song by which the philosopher Nietzsche himself was reportedly "intellectually moved": "I would exchange the happiness of the whole West for the sad strains of a Russian song," were the words that he reportedly exclaimed. Imposing a framework of permissible indulgences does not suit the Russian sense of free will, and produces a devious creature, and not a warrior of the Light of Orthodoxy.

Part of the confusion over setting national priorities stems from the fact

61 The Battle of Debaltseve (or Debaltsevo) was a military confrontation in the city of Debaltseve, Donetsk Oblast, between the pro-Russian separatist forces of the Donetsk People's Republic (DPR) and Luhansk People's Republic, and the Ukrainian Armed Forces, starting in mid-January 2015 during the war in the Donbass region. See https://en.wikipedia.org/wiki/Battle_of_Debaltseve.

62 "'Operation Keelhaul' was carried out in Northern Italy by British and American forces to repatriate Soviet Armed Forces POWs of the Nazis to the Soviet Union between August 14, 1946 and May 9, 1947. The term has been later applied...to other Allied acts of often forced repatriation of former residents of the USSR after the ending of World War II that sealed the fate of millions of post-war refugees fleeing eastern Europe." For additional information on this operation, see URL https:// military.wikia.org/wiki/Operation_Keelhaul.

63 Amended on 6 July 2016, Article 282 of the Russian Criminal Code increased the length of imprisonment for the instigation of hate and enmity or for establishing an extremist organization, being involved in its activities, or financing extremism. See (2016, July 18) Russia: Strengthening the Punishment for Extremism. Global Legal Monitor of the Law Library of Congress. URL https://www.loc. gov/item/global-legal-monitor/2016-07-18/russia-strengthening-of-punishment-for-extremism/. 
that the Russian Federation does not know what type of state it is building. What is wanted is one "with a human face." The uppermost layer of the bureaucracy is already befuddled as it is by the labels "friend or foe," thinking only about bribery and which foreign passport is in which of their jacket pockets. They substitute the word "enemy" with the toothless euphemism "partner." And it wasn't until 13 April 2021, that Deputy Foreign Minister Sergei Ryabkov - after catching a whiff of new emanations from the Kremlin - went out on a limb and called the United States an adversary of Russia. Putin, in his message to the Federal Assembly, compared Russia's enemies to the heroes of a Kipling tale, noting that some of them cling to the Russian Federation for no reason and, like Tabaqui, howl to appease their sovereign. "I hope," said Vladimir Putin, "that it would never even occur to anyone to cross the so-called 'red line' as concerns Russia. We ourselves will determine in each specific case where the line will be drawn." 64 This new Russian foreign policy manifesto has had the effect of Putin's Munich speech. ${ }^{65}$
In approximately the same semantic vein, the head of the Russian Foreign Ministry under Alexander II, Prince A. M. Gorchakov, made it clear to the West that Russia is not giving up its right to vote in European international issues, but is only gathering strength for the future. "La Russie ne boude pas, elle se recueille." ("Russia is not sulking; she is composing herself.") Said more succinctly, "She is concentrating." This phrase accurately defined the political position occupied by Russia after the Crimean War. And three years later, Prince Gorchakov said, "Russia is getting out of that position of restraint, which it considered obligatory for itself after the Crimean War." So now today, Russia has declared its emergence from the stranglehold of a bad agreement with the West made as a result of its defeat in the Cold War; it has declared its geostrategic intentions. It is dangerous to drive the "bear" into a corner. Before you know it, it will mate with a Chinese tiger just to spite of the haughty Euro-Atlantists.

64 President Putin delivered an address to the Russian Federal Assembly on 21 April 2021. In his speech, he cited characters Tabaqui and Shere Khan - a Golden jackal and Bengal tiger, respectively — from Rudyard Kipling's Jungle Book, saying "And of course, all sorts of petty Tabaquis are running around them like Tabaqui ran around Shere Khan - everything is like in Kipling's book howling along in order to make their sovereign happy." (2021, April 21) Presidential Address to the Federal Assembly. URL http://en.kremlin.ru/events/president/news/65418.

65 President Vladimir V. Putin of Russia, addressing an international security conference in Munich on 7 February 2007, accused the United States "of provoking a new nuclear arms race by developing ballistic missile defenses, undermining international institutions and making the Middle East more unstable through its clumsy handling of the Iraq war." See (2007, February 10) Putin Says U.S. Is Undermining Global Stability. New York Times. URL https://www.nytimes.com/2007/02/11/world/ europe/11munich.html. 


\section{Nationally-oriented power is the key to victory in a mental-hybrid war}

The ruling class does a poor job
of meeting the national-patriot-
ic needs of society. Russia is still far from a morally healthy, effective social state which can withstand a "mental war." "For this in Russia," writes the editor of "Russkaya Ideya" ("Russian Idea"), Mikhail Nazarov, "there must be a healthy government that cares about the country and not about its own 'galley' income." ${ }^{66}$ Otherwise, defeat in a world hybrid war is certain.

It is difficult to be a patriot in the Russian Federation given the state ideology of "gas at a discount." 67 This philosophical framework - as the mobilizer of the people to strive for civic engagement, achievement, and labor - was thrown out of the Fundamental Law of the Russian Federation as "Soviet" junk. Moreover, the 13th Article of the Constitution prohibits the establishment of any ideology - "a state ideology or any that is mandatory." They left "ideology" in, if only for practical purposes, to manage society, to prevent social chaos and prevent illegal actions. Would that they had learned from the German pragmatists: "What we believe in doesn't much matter; the main thing is to believe. A people without religion is like a person without breathing." It is no accident that Minister of Propaganda Goebbels admitted: "My party is my church."

While the people do not have their own ideology, the nomenklatura has, for its own needs, "a sort of relatively stable and recognizable system of meanings" --a reliance on a certain value-semantic system. The philosopher Olga Malinova writes about this collision between the two situations: "The potential 'abuse of power' intended to weaken the competitive chances of opponents is obvious, right up to limiting ideological pluralism by prohibiting the expression of certain ideas in public forums...The ruling elite does not have the right to use state instruments of coercion to impose their own ideas as obligatory or to exclude the right to express different points of view." The laws adopted by the State Duma, according to the opposition, are often "occupational" in nature: "Practically all forms of public protest have been declared illegal." The project of capitalism with a human face is failing: the oligarchy is too greedy for superprofits, and the authorities are too stingy to provide any respectable implementation of "social guarantees."

66 'Putin once likened Russian rule to 'galley slavery', but the accompanying four yachts, palaces, airplanes, and glaring luxury help explain why the leader is clinging to the presidency, his implacable critics said." See Gatterman, Steve. (2012, August 28) “'Gallery slave' Putin drowned in luxury, critics say." Reuters. URL https://www.reuters.com/article/orutp-russia-pu tin-slave-idRUMSE87R04820120828.

67 Here, "gas at a discount" is used ironically: In the absence of a real state ideology respected by the people, Russians have to get satisfaction from an ideological surrogate like "discount gas." Similarly, to gain support of, say, Belarus, the Russian Federation - an anti-people state - has to sell gas cheaply to them. (E.V.) 
A more organic course seems to be the saving grace for Russia, the spiritual basis of which will be the Russian idea as a characteristic of national identity and culture. ${ }^{68}$ The national Russian idea is religious and is one that includes providence and predestination. It is holistic and unchanging at its core. Its categories - Spirituality, Sovereignty and Collegiality (in the Uvarov triad, Orthodoxy, Autocracy and Nationality $\left.{ }^{69}\right)-$ are intensely interconnected. "Dissection of this trinity," writes the philosopher V. V. Lazarev, "which was created according to the model and likeness of the triad of Good, Truth, and Beauty, or of the model of the Holy Trinity (an interpretation of the meaning of "the whole made up of three distinct components" or "trinity" as found in Orthodox teachings) - the fragmentation of living spiritual integrity into separate elements - turned this unity into a deathly conglomerate." Without changing the paradigm for the fundamental direction of the Russian Federation - the "nationalization" of the very logic in its thinking, and the strength- ening of the pro-Russian dominant elements - the country will lose not only sovereignty but also vital resources for regenerating the nation. Degradation and depopulation are in full swing. $\mathrm{Pu}-$ tin's mouthpiece, Dmitry Peskov, characterizes the demographic situation in Russia as "very bad."

Everyone is expecting a miracle from the Russian Federation President - to revive the nation - scrubbing the pores of the Russian State's "complexion" to rid it of the comprador oligarchy grime that has become imbedded in it. Then the people will stop acting like cattle and once again find their identity as creators of history, and in inspirational ways, will defend their homeland, which had and still has "only two allies - its army and its navy." ${ }^{70}$ What is needed is an urgent, radical correction of the current course the Russian state is taking, a shift to a patriot-statesman course. Not excluded is a coup scenario for a change in power as is addressed in Kathryn Belton's book Putin's People: How the KGB Took Back Russia and Then Took On

68 "Russian Idea" is a philosophical term for interpreting Russian identity, culture, national and world fate of Russia, its Christian heritage and future, the ways of uniting peoples and transforming humanity. See, among other sources, the entry (no date) Russian Idea. Philosophical Encyclopedia. URL https://dic.academic.ru/dic.nsf/enc_philosophy/9007/русская.

69 "In 1832, a slogan was created by Count Sergey S. Uvarov, Minister of Education...that came to represent the official ideology of the imperial government of Nicholas I...and remained the guiding principle behind government policy during later periods of imperial rule." See (no date) Orthodoxy, Autocracy, and Nationality. Britannica. URL https://www.britannica.com/topic/Orthodoxy-Autoc racy-and-Nationality.

70 On 18 November 2017, a monument was erected in Crimea to honor Tsar Alexander III that bore one of his most famous phrases: "Russia has only two allies - her army and navy." See Sozaev-Gurev, Yegor. (2017, November 18) Vladimir Putin unveiled a monument to Emperor-Peacekeeper Alexander III in Crimea [Original article in Russian: Владимир Путин открыл памятник императору-миротворцу Александру III в крыму]. Izvestiya.[Известия] URL https://iz.ru/672621/ egor-sozaev-gurev/u-rossii-est-tolko-dva-soiuznika-ee-armiia-i-flot. 
the West. ${ }^{71}$ According to a report by A. Aslund and L. Gozman, "Russia after Putin: How to rebuild the state," ${ }^{\prime 2}$ the libertarian "alternative" - not Mikhail Khodorkovsky, ${ }^{73}$ so then Alexei Navalny, ${ }^{74}$ - will not give up without a fight. Some of the premises of this program that are consonant with the slogans of the communist-patriotic ${ }^{75}$ electorate can become a force for consolidating the opposition, for example, with the intention of replacing the "authoritarian kleptocracy" regime or replacing the ruling dynasty of the "Yeltsin Family" which "usurped all the power and most of the wealth" of Russia.
The leadership of the Russian Federation should stop running "a double game - flirting with dwarfs," ${ }^{36}$ as the patriot and systems analyst Sergei Mikheev says. Establish the rule of law. Politically disarm business with ties to government by insisting on "full transparency as to the ultimate beneficial ownership of all enterprises, including media companies." But is there any hope for such a radical transformation of those in power?

Time is running out. The political dynamics in Russia are noticeably accelerating. If the party in power, "United Russia," faces defeat, it can

71 Belton, Kathryn. (2020, April 2) Putin's People: How the KGB Took Back Russia and Then Took On the West. Farrar, Straus and Giroux, 640 pages. ISBN-10: 0374238715, ISBN-13: 978-0374238711. One review describes the work as such: "Catherine Belton deftly tackles one of Russia's biggest mysteries - how did an undistinguished, mid-level former intelligence operative like Vladimir Putin catapult himself to such lofty heights?" Belton is an investigative correspondent for Reuters.

72 Aslund, Anders and Gozman, Leonid. (2021, February 24) Russia after Putin: How to rebuild the state. Atlantic Council. URL: https://www.atlanticcouncil.org/event/russia-putin-rebuild-thestate/. The Aslund report projects the end of Putin's rule and offers thoughts on actions that should be taken by a new government to establish freedom, end repression, establish the rule of law, fix the economy, and build a real democracy.

73 "In 2003, Khodorkovsky argued with Putin at a televised meeting...implying that major government officials were accepting millions in bribes. Unsurprisingly...he was arrested for tax evasion, embezzlement and fraud...and was found guilty...and jailed for eight years." See Dawkins, David. (2020, 14 March) Putin And Khodorkovsky Trade Blows As Presidential Power Grab Gathers Momentum. Forbes. URL https://www.forbes.com/sites/daviddawkins/2020/03/14/putin-and-khodorkovskytrade-blows-as-presidential-power-grab-gathers-momentum/?sh=1101621d2b54.

74 See Harding, Luke (2021, August 19) Alexei Navalny calls for tougher action on global corruption. The Guardian. URL https://www.theguardian.com/world/2021/aug/19/alexei-navalny-callsfor-tougher-action-on-global-corruption-russia-kremlin-putin. Jailed Russian opposition leader Alexei Navalny dictated from behind bars a plea "to urge western politicians to take meaningful action against global corruption and to impose personal sanctions against oligarchs in the entourage of Vladimir Putin."

75 The term "communist-patriots" is sometimes used to refer to political forces that preach communist and ultranationalist ideology. Alternatively, terms such as "communofascists" or "red-browns" also appear to be used to describe "communist-patriots. URL https://ru.m.wikipedia.org/wiki/ Коммунофашисты.

76 The Kremlin is playing a double game in that it wants the support of the "dwarfs" - a euphemism for 'the liberal minority' - and also wants the people to be satisfied. (E.V.) 
replace the presidential form of government with a parliamentary one. A parliamentary form of government, by definition, is more transparent and democratic, and most importantly, if the country collapses, the responsibility will be borne collectively. Alternatively the presidential form of government could be replaced by a model whereby there is a State Council and a collective leadership - a combination of the Politburo of the Central Committee of the CPSU and the State Council of the People's Republic of China.

What kind of leader do the people need at a new stage of development? Political scientist Mikheev (member of Zakhara Prilepina's For Truth party) answered this question in detail: "In foreign policy, there is a more robust project that will restore historical justice... In domestic policy, the economy should be a means for organizing people's lives, not one for making profit. The shape that national culture takes should not be subject to economic control. In a moral and ethical context, the ideals of traditional religions should be dominant in the formation of informational content and cultural policy. A person who would advance these three hypostases...I don't see such people."

And where can we get such "triadic" leaders if "outsider" candidates are filtered out from the list of candidates running for president, the list which tightly blocks the entry of the "not ours" to political Olympus?! The "production line" of officials possessing the given parameters required by those ruling the Russian Federation forms a "secret stash" for nomenklatura appointments. "Cadres decide everything," said J. V. Stalin. The difficulty in choosing a worthy presidential candidate possessing the three characteristics (as mentioned in the "triad" discussion above) is understandable, and is the eternal sin of the intellectuals: they are painfully far removed from the people. The "singer" of the people's monarchy, Ivan Solonevich, ${ }^{77}$ blamed this social class for its unwillingness to see itself "as a layer subordinate to the main Russian historic lines of development, rather than a cooperative of innovators, vying with each other to promise the Russian people the "stars" - false promises - stolen from non-Russian philosophies and a world that completely reconstructs and alters our thousand-year statehood."

All spheres of Russian life - its politics, economy, and culture - should become items of national priority. And in international relations, without the ability to defend the interests of the country, there can be no respectable and compelling diplomacy. The negoti-

77 Ivan Lukyanovich Solonevich authored “The People's Monarchy," originally published in newspaper installments starting in 1951. The book offers Solonevich's view of the history of Russia, an analysis of the current geopolitical situation in the world, and an exposition of the ideology of the "People's Monarchist Movement." Here Solonevich is referred to as a "singer," a reference to the "singer-poet" in the V. A. Zhukovsky poem "Singer in the Camp of Russian Warriors" (1812). In the poem, the poet who loves his Fatherland...directs a fiery speech to the soldiers...because they have one goal - to protect their country. An analysis of the poem can be found at URL https://en.sodi ummedia.com/4176103-quotsinger-in-the-camp-of-russian-warriorsquot-zhukovsky-analysis-ofthe-poem-the-plot-and-literary-trails. 
ation process should operate not within the framework of whatever provides instantaneous benefits for business (as it is now), but within the framework of civilizational-national global interests. Since international security by treaty has not worked in previous regimes, we need to build a new system to handle current situations - a new system for interconnecting states - and one that harnesses the arsenal of tools for averting both direct military aggression as well as indirect forms of aggression such as economic-political and hybrid-ethical ones.

"War is the art of deception," Sun Tzu said. We will have to proceed from the given that the principle of the non-use of force or the threat of force as an instrument of national policy (the Paris Pact of Kellogg-Briand) ${ }^{78}$ has given way to the law of war - jus ad bellum. ${ }^{79}$ And the past achievements in the art of virtuoso diplomacy (including the practices of "Mr. No" - Andrei Gromyko) have gone to rust due to their prolonged disuse.

The US strategy of "forward defense" is applicable in "cyber diplomacy" (my term - E.V.) as well. This rapprochement with the enemy is established as close as possible to see what he is planning, and in response, to prepare to or to actually take appropriate measures. This is the actualization of "reconnaissance in force." Forward-looking, all-encompassing both in strategic planning and in operational development, multiplied by the ability to pursue the enemy during his maneuvering, with an understanding of how he develops as a dynamic object. In this regard, it is important to take into account the updated specifications for diplomacy in an era of globalism and postmodern conflictology put forward by the new head of the CIA, William Joseph Burns: "The conflict among the great powers requires subtle diplomacy; you need to maneuver in the gray zone between peace and war, know the limits of what is possible, build levers of influence, pursue common interests where you can find them, and firmly and consistently confront [Russia] where no common interests exist." Intelligence under Trump became noticeably politicized. It is precisely the unbiased, objective analysis of Burns, the career diplomat and man who "earned his gray hair on Russia," that Biden has probably heard and that the Kremlin has sufficiently come to understand. "New thinking" (yes, not as Gorbachev viewed, but rather, the Realpolitik of Bismarck) - one without illusions and ideological dogmas.

The drive to ease tensions in bilateral relations is enticing. Playing cards with an open hand (albeit with hidden trump cards) draws the opponent's attention away from his "red lines" for the sake of reaching a mutually beneficial compromise. This fact it-

78 The Kellogg-Briand Pact, sometimes called the Pact of Paris, was an agreement to outlaw war signed on August 27, 1928.

79 The Latin term "jus ad bellum" refers to the conditions under which states may resort to war or use armed force in general. The prohibition against the use of force and the exceptions to it were set out in the United Nations Charter of 1945. 
self is important: the "outcasts" become engrossed in dialogue. And then comes the art of bargaining over multilayered enticements. In doing so, the West unites around a common benefit arising from the dialogue - a benefit both for the EU and one that is in the interests of the United States. This is the test of "reconnaissance in force" initiated by Russia and China to strongly support their integration into a globally pan-civilizational project of unified values and common governance in the postCOVID era. By leveling the separate, distinctive national characteristics and replacing them with soil for compromise, the concept of "enemy" disappears because there is no one to fight with.

Bilateral dialogue sets the jurisdictional boundaries for each of the parties as well as their limits for tactical retreat, which are no further than the distant boundaries of their national priorities. As a result of settling on how agreements and clarifications are handled, the strategic boundaries of a new agile configuration are worked out. This is fluid diplomacy and not a set-instone dogma of "having to fulfill marital obligations" by those who have not loved each other for a long time. The time for sluggish geopolitical initiatives and doctrines is over. A confrontation of fully-armed systems calls for reduc- ing tensions among the warring parties. The strategy of applying compressed pressure (as I would call it - E.V.) corresponds to this situation: Today, the West and China are not in the best condition. And each of the geopolitical actors is seeking to avoid "zeitnot" 80 - to not be faced with having to put their stronger players in zugzwang ${ }^{81}$ where any move will lead to a worsening of his position. The stakes are high: a global war, or a return to the status quo of "no war, no peace."

Most likely, Putin's remarks on "Munich-2" ${ }^{22}$ were just brutal patriotic rhetoric. Indeed, in the ruling circles, until their capital abroad is confiscated, entirely different aspirations will prevail: for the Kremlin (Yeltsin) "family," it is to seek revenge and to maintain the predatory comprador-oligarchic course.

Anything can happen. After all, those in power do not adequately react to serious cataclysms in society: they do not read the signs and signals from the people and therefore lose their already negligible support and legitimacy. The authorities cannot, says expert Valery Korovin, demonstrate "arrogant alienation" and address the people only when elections need to be held or when unrest and riots begin. "The reaction of the authorities is extremely transient, is one

80 A German chess term meaning time pressure, or literally "time emergency." If you are playing a timed chess game and you are very close to having used up our entire allowed time for the game, you have a zeitnot on your hands.

81 Zugzwang is a German term that means "a compulsion to move." In chess, it refers to a player having to take his turn and make a move even though any move will put him in a worse position.

82 A reference to Putin's appearance on Munich Channel 2 television during which he accused the US of undermining global security in the wake of an international security conference held in Munich in February 2007. 
of irritation, is unsettled, and has only a one-time impact on the situation. The powers that be relate to the masses as if they were some sort of set of mechanical implements." A survey was conducted and statistics were compiled; a decision was made without actually listening to the people, without considering the nuances or the details. As a result, the state has lost its foothold. There is a double zugzwang: the authorities and the opposition; the West and Russia.

As soon as Putin started talking about a red line, Patriarch Kirill warned the authorities against turning into a tyranny. What does the coming day have in store for us?! On the part of the ruling establishment, the continuation of a weak, cowardly, vague policy will provoke an explosion of popular indignation, and the mobilized spurt of support - enthusiasm for the initiative associated with the movement of Krymnash - will wither on the vine. ${ }^{83}$

It is impossible to test the patience of the nation that has been seeking positive changes for a long period of time. The establishment will wait, it seems, until the people themselves move to storm the regime singing the song "Get up, the country is huge!"
Then the red line itself will be drawn along the distant security borders of the Homeland. And that line will no longer pass through Kiev, but through Warsaw. More likely than not, Putin, by waiting to attack only at the most suitable, opportune moment, found himself late in responding to the announcement of John Bolton, at the NATO summit in 1999 where he pointed to a red line that then ran from the Baltic to the Black Sea - on one side of which lies "the civilized world, and on the other - Russia."

A retinue rules as the head of the Russian Federation. Even if Putin wanted to radically change the corrupt oligarchic system, he would be prevented from doing so by the environment that surrounds him - one aimed at operating collaboratively and opportunistically. And most importantly, he himself, fearing the red-brown revenge of a USSR-2, is, we could suppose, more afraid of the systemic popular-patriotic opposition than of any Western expansion. Therefore, he is a priori closer to the West than he is portrayed. The West, then, should correct its course as concerns the Kremlin: it should not denigrate the President of the Russian Federation, but, rather, prolong his rule

83 Goble, Paul. (2015, June 10) "Krymnash" Meme Part of Russian Society's Return to Late Soviet Times. Euromaidanpress. URL http://euromaidanpress.com/2015/06/10/krymnash-meme-partof-russian-societys-return-to-late-soviet-times/ According to the article, "Krymnash' [Crimea is Ours] arose as a serious meme in March 2014, an expression of the patriotic pleasure Russians felt in taking Crimea and demonstrating the power of their country. But since then, it has become an ironic expression, one that recalls Soviet times, and the people use it as almost a throw-away line - 'our toilets don't work but at least Krymnash!....And it is an indication that in the minds of the populations 'whatever happens in Russia, it will all the same remain an unsuccessful state and life will be bad."'

84 he title and first line of "Get up, the country is huge!" The song was the creation of the poet Vasily Lebedev-Kumach and the composer Aleksandrov, and was composed on the night of 22 on to 23 June 1941. Germany attacked the Soviet Union on 22 June 1941. 
of the country by allowing him to gain and in doing so, keep the Russian Fedmoderate concessions from the West eration in its orbit.

Dr. Eugene A. Vertlieb is a Russian-born dissident bearing US citizenship and currently living in France. He received a B.A. at Leningrad (Sankt-Peterburg) State University, a PhD at the University of North Carolina, and completed a postdoctoral internship at the Russian Academy of Public Administration in the Russian Federation. Dr. Vertlieb has held a variety of positions including Professor at the Marshall European Center for Security Studies, Germany, and at the Institute of International Relations (US). He is an author of several books and articles on geopolitics. Dr. Vertlieb has also served as Political adviser to the Committee on International Affairs and International Relations, Kyrgyzstan. He is currently President of the International Institute for Strategic Assessments and Conflict Management (IISACM-France); Executive Director of the Western Policy Forecasting Department for Slavic Europe, (Munich, Germany); and Executive Member of the Lisbon-Vladivostok Initiative (France).

Dennis T. Faleris received a B.S. from the University of Michigan and a Master's Degree in Russian Linguistics from Georgetown University. Mr. Faleris worked as an instructor, translator, senior intelligence analyst, and manager at the National Security Agency for more than thirty-five years. He currently resides in Annapolis, Maryland. 



\title{
Проект Путин-2024 в геостратегии противостояния и внутренних вызовах
}

\author{
Д-р Евгений Александрович Вертлиб
}

«Новый мировой порядок будет строиться против России, на руинах России и за счёт России» (Збигнев Бжезинский)

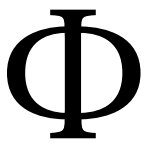

ранклин Делано Рузвельт завещал, что без России не обойтись. Но в послевоенном мире возобладал жёсткий подход к России, основанный на Фултонской концепции Сэра Уинстона Черчилля: только тотальная и бескомпромиссная борьба «стран свободы» с «тиранией». И иметь надо подавляющий перевес в военной силе, который и должен обеспечить «взаимопонимание с Россией». «Больше агрессии» в отношении России и Китая - взывает в наши дни флотоводец адмирал Джон Ричардсон. Балансирование на лезвии бритвы - срыва в войну. Но порой действия говорят громче слов. В жёсткой конфронтации с КНДР воинственная риторика американцев не соответствовала скрупулёзному соблюдению ими «красной линии» чётко прочерченной Пхеньяном.

Поскольку баланс сил - общий принцип равновесия в современных международных отношениях, то ведение войн оправдывается соображениями установления «баланса» или «равновесия». С распадом СССР закончилось равновесие взаимосдерживающих сил и возник соблазн безнаказанного удара по ослабевшему онтологическому врагу.
«Старая доктрина равновесия сил теперь непригодна. Мы не можем позволить себе, - заявил в 1946 году Черчилль, - действовать с позиций малого перевеса, который вводит во искушение заняться пробой сил». И Китай более не придерживается своей прежней ядерной доктрины «минимального сдерживания». Тестирование сил и средств противника, вплоть до разведки боем становится повседневной нормой взаимоотношения сторон противостояния. «Я не собираюсь требовать от своих командиров принимать первый удар в челюсть», - заявил недавно командующий ВМС США в Европе и Африке адмирал Роберт Беркю. А прецедент безнаказанности приштинского марш-броска российских десантников? Так что вряд ли корабли НАТО в территориальных водах РФ откроют огонь на поражение по российским кораблям. На ядерный шантаж же у РФ есть торпеда «Шквал», способная, как пишут в СМИ, изменить военный баланс - «покорить весь мир».

Запад победил в холодной войне, но проигрывает холодный мир. Победителей подвело высокомерие и ложная уверенность, что с конкурирующим центром силы покончено навсегда. Фридрих Великий 
предостерегал на этот счёт: «русских мало убить, нужно ещё и повалить». Большой стратегической ошибкой было упустить благоприятный момент для полной «привязки» России к Западу в пору, когда она была к этому готова. «Время Ч», выражаясь оперативным языком военных, проиграно.

Россия, удержавшись на грани небытия, смогла не только устоять, но и успешно соперничать с Западом по гиперзвуковому и космическому оружию (будущие конфликты будут решаться в космосе). Растущая сила и возрожденческая устремлённость РФ вылились в боевую риторику В. Путина: «Даже если бы мы потопили этот корабль, мир не оказался бы на пороге мировой войны» - заявил президент по инциденту с британским эсминцем Defender. И обычно уклончивый политический нарратив Китая вдруг стал недипломатично резким: Председатель КНР Си Цзиньпин в речи по случаю столетия правящей Коммунистической партии пригрозил «разбить голову в кровь о стальную стену» тем, кто вмешивается в его внутренние дела.

Китайцы почти вдвое увеличивают свой ядерный потенциал.

Инвестируя в укрепление своей ядерной мощи, Китай добивается сразу нескольких целей: совершенствование ядерных, обычных сил и противоракетной обороны. Их ракеты DF-41 способны поражать цели на расстоянии более 14 тыс. км. При обилии в их ракетных шахтах пустышек, трудно распознать где спря- таны от первого удара комплексы с гиперзвуковыми планирующими крылатыми блоками или ракеты-перехватчики для противоракетной или противоспутниковой обороны. Вместе с российскими оружиями «Циркон», «Посейдон», «Сармат», «Кинжал», «Пересвет»... - арсенал внушительный. Выражаясь в терминах евразийца П.Н. Савицкого (1959 г.), ломается «под самый корень рог западной гордыни». Конец двуполярного мироустройства по эффекту сравним с природным катаклизмом - разломом земной коры: Северо-Американская и Евразийская тектонические плиты разошлись и возникли гигантские рифты. А ныне однополярное американское доминирование более не устраивает ни РФ, ни КНР, а складыванию многополярного мира препятствуют США как угрозе своей национальной безопасности. Третий по ядерной мощи Китай принимает концепцию ответно-встречного удара, наподобие российской.

Антироссийские санкции и рестрикции оказались мало эффективными. И более того: тогда как в США забуксовала было экономика - до 15\% от мировой (примерно как в СССР при Горбачёве), и американские денежные активы стали не столь стабильны (испытывают риски ликвидности и избыток денежных средств), Россия умудрилась нарастить золотой запас и вместе с КНР изъять свои национальные валюты из долларовой «зоны риска». И уже не только о распадных процессах в России пресса талдычит, но 
и о том: а не разбединятся ли Соединённые штаты Америки на 51 самостоятельное государство (если округу Колумбия придать статус нового штата).

Россию не перестали считать «Верхней Вольтой с ракетами». Президент Джо Байден лишь контент актуализировал: охарактеризовал эту страну с восьмой по размеру экономикой в мире как лишь «с ядерным оружием и нефтяными скважинами и больше ни с чем, ни с чем». «Россия - объективно ослабевающая страна в экономическом и демографическом плане» - считает глава британской разведки МI 6 Ричард Мур. А с такой жутковатой демографической кривой как в РФ стране подумать бы о выживании. Да и правящий олигархат отнюдь не стимулирует народ на труд и подвиг. Как верно сказал Рейхсляйтер пропаганды Йозеф Геббельс, «пушки и штыки - ничто, если вы не обладаете сердцами нации».

Инструментарий западного воздействия на Россию инерционен: чередование «кнута и пряника» - санкицй и вовлечения. Однако былой либертарианский облик РФ, мелькнувший в «лихие 90-е» и вскоре померкший, так и не воскресает. И вряд ли этот пугающий россиян жупел обманутых надежд явится снова. Ведь пройдена «точка невозврата» сей догмы. Однако Запад не приемлет складывающийся новый мироуклад и продолжает дожимать уже недожимаемую Россию, как и единолично арбитражить в острых международных спорах, не считаясь с консенсусом иных мнений. Судя по реплике пресс-секретаря президента РФ Дмитрия Пескова на вышеприведённое высказывание Джо Байдена, «тут налицо ошибочное знание и понимание современной России». А это уже просчёт западной системной аналитики. Ведь недостоверное знание истинного политико-психологического состояния СССР и недооценка стойкости русской экзистенции стоили виселицы имперскому министру Иностранных Дел Иоахиму фон Риббентропу. Россия - далеко не «колосс на глиняных ногах» и не «просто страна-бензоколонка». Она по духовной оснастке, как мне представляется, - западный доминион, некий симбиоз недоколонии и недоимперии. Нельзя недооценивать Россию.

Как показал Александр Солженицын в своей статье «Чем грозит Америке плохое понимание России», манипуляция фактами о России привела к тому, что «весь Запад попал в критическое и даже смертельно-опасное положение». Абсурдно обвинять Россию во всех смертных грехах, в том числе и происхождении тоталитаризма. Ведь вовсе не «император Николай I» изобрёл тоталитаризм, как приписывается Ричардом Пайпсом. Идею тоталитарного государства первый предложил Гоббс в “Левиафане” (глава государства господин не только над имуществом и жизнью, но и совестью граждан). Да и Руссо давал к тому основания, объявляя демократическое государство «неограниченным сувереном не только над собственностью, но и 
над личностью граждан». Как гласит русская пословица, «На зеркало неча пенять коли рожа крива».

России проигрышно быть «пешкой» в чужих играх и в принятии своих решений руководствоваться одобрением как коллективного Запад («новая Антанта»), так и Китая. Для неё первостепенна задача восстановить свой исконный мировоззренчески-геополитический «код», представляющий собой совокупность ключевых представлений россиян о своём месте в истории и мире, внешнеполитической стратегии и национальных приоритетах. Как китайцы в политике: по всем договорам неизменно требует «дуйдэн» - паритета взаимоотношений, мер u шагов. В соответствии с духовным концептом «инь и ян» («хаос и порядок»): упорядочивание сущностей прекращение действия хаоса.

Россия нацелена на выход из изоляции в возобновление конкуренции уже трёх мировых систем. Она готовится к асимметрично-бесконтактной войне по достижению политических целей без открытых военных действий. Вырабатывает навыки ведения сетевой кибервойны, особенно против коммуникаций и систем логистики; умение противостоять вылазкам «Пятой колонны», включая саботаж и подрывную деятельность; атакам на финансовую инфраструктуру и информационные операционные системы. Пытается держать порох сухим. Ведь риторика войны всё громогласнее. 24 января 2021 Кремль заявил довольно решительно, что Москва не готова $\kappa$ диктату и хамству. "С русскими стоит или играть честно, или вообще не играть» - завещал «железный канцлер» Отто фон Бисмарк.

Стратегии и тактики воздействия на противников и оппонентов нередко выглядят сомнительными. Так, одновременный прессинг России и Китая вряд ли целесообразен, поскольку мало эффективен, зато способствует консолидации этих «изгоев». И в отношении Минска радикальная тактика продвижения демократии любым путём, вплоть до госпереворота, оказалась проигрышной. В результате фальстарта, или неточного замера сложившейся ситуации, или недоучёта субъективного фактора случая, рухнул план по смене режима - что лишь ускоряет интеграцию Белоруссии в Россию. А судя по статье Владимира Путина «Об историческом единстве русских и украинцев», понятно, что и на Украину у Кремля есть свои виды. Участившиеся проколы в стратегическом планировании и в реализации замыслов подтверждают то, что заметно качнулся мега-проект по унификации («аксиологической стерилизации») незападных цивилизаций для универсализации общих ценностей. В системной аналитике такие недочёты могут быть фатальными.

Но указанные эти и другие (по Сирии, Ирану, Афганистану) западные просчёты компенсируются российским неумением (или нежеланием?) грамотно воспользоваться ошибками противника. На принятие решений сказываются тотальная 
коррупция, при «денационализированных элитах» и расконсолидированном обществе. «Россия может иметь сколько угодно ядерных чемоданчиков и ядерных кнопок, -- саркастично заметил Збигнев Бжезинский, - но поскольку 500 миллиардов долларов российской элиты лежат в наших банках, вы ещё разберитесь: это ваша элита или уже наша? Я не вижу ни одной ситуации, при которой Россия воспользуется своим ядерным потенциалом». Метод подчинения государства с помощью приручения его элиты известен с античных времён. Так, панически боявшиеся скифов древние греки пытались их если не покорить, то хотя бы обезопасить свои полисы от их набегов, приобщив их вождей к греческой культуре. Однако, как сообщает Геродот, если скифские цари начинали придерживаться греческих обычаев, их подданные безжалостно их убивали.

Президенту Путину хотелось бы видеть российский народ сплочённым и монолитным. Но пропасть разрыва между правящим олигархат и «нищебродом» (остальным людом РФ) только разрезается. Зачистка электорального поля от кандидатов, неугодных правящим кругам, подтверждает тот факт, что В. Путина готовят на очередной президентский срок, или же его креатуру типа «всех устраивающую» - С.К. Шойгу. Этой фигурой в случае форс-мажора можно бы и военной диктатурой припугнуть «маловменяемых» и «отморозков».
Так что с неизменностью курса стабилизации стагнации придётся считаться как внутренней оппозиции, так и Западу. С ростом протестного движения следует ожидать ужесточения репрессивных мер по «наведению общественного порядка» (при эскалации же «несанкционированных действий» «восстановление конституционного порядка»). Кто-то из борцов за лучшее будущее России предпочтёт сотрудничество с «путиноидами», тогда как большинство выкинутых из достойной жизни россиян обречено на борьбу за существование, «маргинализацию» и открытое противостояние постбеловежскому строю B.O.P. (временно оккупационному режиму). При таком варианте судьбы России власть у «Единой России» наверняка вырвут патриоты-государственники «единого русского народа: русских-украинцев-белорусов». Не исключено, что для вскрытия постбеловежского нарыва на теле Отечества может понадобиться небольшая гражданская война.

Выражаясь циничным языком политики: чтобы «красно-коричневые» не смели компрадорско-олигархическую власть (на манер изгнания в 1612 поляков из Москвы), Западу прагматичнее было бы перестать шельмовать Путина (он ведь внутренне весьма лоялен Берлину, но обижен Вашингтоном), а попытаться как равновеликого по-настоящему опартнёривать вместе с его свитой - хотя бы по тактическим соображениям выгоды: дать мухе завязнуть в смоле янтаря. Ведь Рос- 
сия уже вряд ли вернётся к либертарианской модели, а коли подлинное народовластие путинистам неприемлемо, они и сдерживают его всеми силами. Они с Западом в этом смысле стратегические попутчики. Посему Вашингтону и Брюсселю (Берлин и Париж - уже) не целесообразней ли было бы сменить парадигму отношения к России - хотя бы не мешать путинским импровизациям по благоустройству РФ под лозунгом «это вам не 1937 год!». А как таковая «подрывная деятельность» при таком попутничестве позиций вообще не понадобится. Ведь режим-то наибольшего благоприятствования Западу, при минимальных дивидендов России. Стратагема не мешай падать в нужном направлении. А помогать, как ни парадоксально, логично «левому повороту» умеренных спецов и государственников-патриотов, способных по-настоящему консолидировать народ и поднять экономику (как правительство Примакова-Маслюкова) и стать притягательной державой евразийско-цивилизационной сердцевины Земли.

Выводы:Путину - не мешать (и что касается российско-германского газопровода), от Чубайс-Навальных «либерал-диктатуры» - отказаться (проект сам себя изжил) и вложиться в реальную перспективу смены власти на технократико-патриотическую. Ведь надёжнее всего было Западу вести дела со сталинской предсказуемостью и позиционной ясностью. Предложенной стратегии делового сотрудничества придерживалась сперва сама Кайзеровская
Германия - помогала одновременно и «Белым» (не мешала), и «Красным» (усиливала) России. Русский иоанновский человек жив не «хлебом единым»-рационализмом, а духом.

Да и принципы реалполитик о том же: разделяй и властвуй; Не ставь всё на одну карту. Американцы не раз блестяще демонстрировали своё стратегически-многоходовое видение перспектив глобальной безопасности. Так, чтобы минимизировать тяжёлые последствия от надвигающегося кризиса 1929, США тайно решили принять превентивные меры по изменению расстановки сил в мире. «Для этого понадобилось оказать помощь России, чтобы она окончательно избавилась от разрухи - последствий гражданской войны, и помочь Германии избавиться от тисков Версальского договора», - констатирует факт разведчик-нелегал генерал Юрий Дроздов.

Хотя западному истеблишменту предстоит менять отношение к России, Конгресс США пока всё ещё директивно запрещает теперь уже Байдену (как раньше Трампу) улучшать отношения с Россией пытаясь заблокировать (оказалось, безуспешно) президентское право отказаться от санкций против российского газопровода «Северный поток-2». Прежде всего это бизнес-проект. А насколько он станет «геополитическим оружием» - зависит во многом от самого Запада: гибкого управления газовым вентилем. Новый виток холодной войны, начатый Обамой, замедлился было при Трампе, при макроновском посыле 
«Отталкивать Россию от Европы - это глубочайшая стратегическая ошибка». Но здравый прагматизм не возобладал.

Позиции сторон конфликта понятны. США, сохраняя свою мировую доминируюшую роль, препятствуют усилению соперничающего центра силы. В России же возрождение национальной идентичности призвано вернуть общество к православням корням, с забвением которых меркнут христианские идеалы как нравственно-цивилизационный консолидант - социум хаотизируется, фрагментизируется и духовно мертвеет. Поскольку распадаются социальные страты на конфликтующие этно-конфессиональные сообщества, подверженные массированной дехристианизации и дегуманизации - обезбоживанию и деструкции. Россия архаччески национальна, тогда как Запад оперирует на наднациональном уровне, переставая коррелировать с традиционными обществами и «устаревшими нормами» международного права. Естественно, вспыхивает казус взаимоотношений между Западом и Россией.

Табуизация Конгрессом США самой возможности сближения с РФ знаменательна. Как Российскую империю в своё время порешил вброс чуждых интернационалистских идей, разрушивших верования, так и духовный монолит США качнулся, когда американский истеблишмент с 1960-х пристрастился к идеологии неомарксизма франкфуртской школы. Правящую элиту, изменившую тогда главенствующей консерва- тивной традиции, понесло вразнос. Последовавшая идеологическая индоктринация (заимствование чужой доктрины без критического осмысления) «философии практики» (praxis) итальянского марксиста Антонио Грамши аукнулась ныне -сработал тот теоретический вброс: обоснование раскола общества на мозаччные страты и сплочение их вокруг тевых элит под тозунгами борьбы с «угнетением» и за безграничные свободы. Демократический истеблишмент возвращает историческую справедливость одной страте за счёт ущемления в правах другой. Традиционное американские общество деформируется до неузнаваемости прививкой левацкого троцкизма с примесью «хунвейбинизма» (китайской «культурной революции») и классовой ненависти («кто не с нами, тот против нас»). Доподрывали США и Россия друг друга - обе сверхдержавы подорваны чужими идеологиями и у разбитого корыта, на радость гегемонирующему коммунистическому Китаю!

Если дипломатия - это искусство возможного, то Конгресс США делает её невозможной с Россией. А там где останавливается дипломатия, начинается война. Перманентная холодная конфронтация между сторонами конфликта перемежается примерно раз в столетие вспышкой горячей войны, а затем детантной паузой передышки-«перезагрузки» для выверки целей и средств поражения или достижения их. Конгресс и зафиксировал состояние войны «иными средствами». 
Каждый век большая война Запада с Россией. 1612 - Минин и Пожарский изгнали поляков из Москвы. 1709 - Пётр Первый разгромил под Полтавой шведского короля Карла XII. 1812 -Кутузов остановил вторжение армий Наполеона. 1914 - начало Первой мировой войны. 2014 - операция «Крымнаш» трансформировалась в новый тип войны - гибридной.

И в геополитическом аспекте Евразийская Россия, Heartland -- ось истории и желанный трофей в противоборстве. Евразия, с российской её сердцевиной и китайской обочиной, была и остаётся важнейшей геостратегической мишенью оппонентов. Основополагающ для военных и дипломатических усилий базовый тезис британского геополитика Сэра Хэлфорда Маккиндера: кто контролирует хартленд - тот контролирует весь мир. За эту сердцевинную часть Земли, включающую южное подбрюшье России (полное руд и водных ресурсов), воевать будут всегда. «Британское евразийство» заявило о себе в XVIII веке Уильямом Джонсом. «Большая игра» по Маккиндеру - это противостояние Англии и Российской империи за контроль над евразийским материком не только в стратегическом плане, но и миссия нивелирования этно-культурных отличий. Последователь Маккиндера Збигнев Бжезинский в своей книге «Великая шахматная доска: главенство Америки и её геостратегические императивы» (“The Grand Chessboard: American Primacy and Its Geostrategic Imperatives") акцен- тирует внимание на геополитической стратегии США относительно Евразии. В “Стратегии национальной безопасности” 2002 американцы определяют себя как евразийскую державу, а Евразия - приоритетный для них регион XXI века.

И «Готская цивилизация» пангерманистов претендует на Причерноморье, с геополитическим проникновением в Азию. Но великий фон Бисмарк предостерегал: «Даже самый благополучный исход войны никогда не приведёт к распаду России, которая держится на миллионах верующих русских греческой конфессии. Эти последние, даже если они вследствие международных договоров будут разъединены, так же быстро вновь соединятся друг с другом, как находят путь друг к другу разъединённые капельки ртути». Черчилль подсказывает: «Россию невозможно победить силой, её можно уничтожить изнутри».

Российский сфинкс пытаются распознать не познавательно (какой она есть), а противопоставительно (какой хотелось бы видеть). Поэтому получаются абсурдные умозаключения, типа: «Что русскому хорошо, то немцу - смерть». А ведь эти народы сопряжены между собой, как Фатерланд и Мать-сыра земля. Германские этнографы сочли славян арийцами; это хорошо видно на карте XIX века из библиографического музея города Лейпцига. Артефакты древности от Рейна до Верхней Волги говорят о славяно-германской общей «культуре боевых топоров (или шнуровой 
керамики)». У тевтонцев праславянские гены от племён поморян, руян, бодричей, лютичей и лужичан. А по «Великопольской хронике» немцы и славяне - кровные братья (germo): Ян (славянская ветвь) и Кус (немецкая ветвь). Сыновья отца Яфета.

И всё же «Запад есть Запад, Восток есть Восток, не встретиться им никогда» - пишет британский поэт Р. Киплинг. Однако он допускает возможность честного диалога между ними: «когда двое сильных $и$ смельхх мужчин друг другу в глаза гля$\partial я m » !$

В реальности впечатления от встреч лидеров обеих стран с глазу на глаз оказались противоречивыми: Байден не разглядел у Путина душу, которую увидел Буш-младший. Чекист, с кредом «равнения на дзюдоиста», не расшифрован.

\section{Русская непредсказуемость. аполитичность элит и патриотизм российского народа-факторь, влияющие на принятие решений}

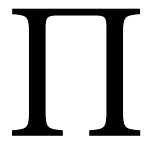

оскольку «умом Россию не понять», а знать её необходимо, взглянем под стратегическим углом зрения на её «особость». Русские, очевидно являясь в этническом, антропологическом и культурном плане европейцами, при этом функционируют и мыслят как-то иначе. Изначально они поведенчески странны, «византийски инакомысленны» в сравнении со структурированными западными рационалистами: приглашает варягов править собой. Это предательство национальной элиты? Или головотяпство «глуповцев»? Однако всё вполне логично: был резон пригласить «варяжских гостей». Ведь шведы многому научили «русичей». И ментально поступок соответствует русскости: держаться подальше от начальства и быть индифферентными к «неинтересному» им. Вроде как «моя хата с краю - я ничего не знаю» - подчёркивание безразличия человека к какой-то конкретной ситуации. Но у этой фразы двойной смысл. Сопутствующая коннотация пословицы такая: «моя хата с краю - первым врага встречаю». По поводу трудностей в понимании русской иносказательности в словах и делах Черчилль обречённо констатирует: «Я не могу предсказать действий России. Это головоломка, завёрнутая в тайну, завёрнутую в загадку».

Россия - симбиоз Европы и Азии в ментально-культурном и геополитическом планах. Она - одновременно и наследница Византии - хранительница духовного света Христианства, и Золотой Орды - боевой крестительницы на победу в войнах. В России слились два основных этнических компонента: славяно-кельтский и скибо-сарматский (иранский). Этот синтез образовал особую цивилизацию, по этнокультурным характеристикам отличающийся как от европейского, так и от азиатско-буддистского и азиатско-исламского типов. В треугольнике Рось-Киев-Днепр до прихода сюда восточных славян обитали 
иранские племена киммерийцев и скифов, передавшие русичам свой скибо-сарматский этнокультурныи код и наименование. Вероятно, дух воинственных предков воскрешён ныне в самом названии грозной межконтинентальной баллистической ракеты РС-28 «Сармат» (сменщик «Воеводы» - модификация «Сатаны» способна преодолеть любую систему ПРО, достигая свои цели через Северный или Южный полюс). Русским скифам «нечего терять, и нам доступно вероломство!» - обронил поэт Александр Блок. Отблеск русского трагического максимализма и на устах В. Путина: «Зачем нам мир, в котором не будет России?». Всё, или ничего. В древнем византийском источнике «Стратегиконе Маврикия» зафиксировано, что славяне не приемлят рабства ни в какой степени: «...будучи свободолюбивыми, они никоим образом не склонны ни стать рабами, ни повиноваться, особенно на собственной земле». Поэтому с такими или на равных вести дела, или не работать вообще.

Если бы Россия пошла по новгородско-скандинавскому пути -- Скандославия (союз славян и скандинавов) vs. Киевская Русь -- то стала бы более евроориентированной. В викинго-норманнской теории происхождения русского народа закреплена «многонациональность» Рюрика»: он и скандинав-датчанин (конунг Рёрик-Hrorek из ютландского Хедебю-Дания), и славянский «сокол» с родовым именем рарог, и внук новгородского князя Гостомысла (сын его дочери Умилы и со- седского князя). Россия разошлась с Европой в XI веке в результате раскола Вселенской церкви и отпадения от неё католиков. При этом православие стало базисом и стержнем русского менталитета, определило его шкалу ценности и устремления. Русско-варяжский выбор русичей стал фундаментальной основой консолидации племён и образованию «Земли Русской» -- прообразом Российской Империи, с русским Богом и имперским чёрно-жёлто-белым флагом.

Россия зарекомендовала себя практически неодолимой в войнах. Потому эту строптивую непокорность укрощают из вне «петлёй анаконды», а изнутри - вспениванием смуты социальных потрясений с помощью «пятоколонников»-коллаборационистов-смердяковцев, мечтающих об оккупации России «просвещёнными странами» и о возвращении РФ к пределам «мшистых топких берегов» малообитаемого Севера. В российском политическом лексиконе таких именуют «гнилой интеллигенцией». Сей термин перекочевал от императора Александра III к В. И. Ленину. Советский лидер Н. С. Хрущёв обозвал художников-авангардистов «педерастами» за их общественно-политическую ничтожность. Безыдейная интеллигенция не нужна была советскому народу и государству, ибо не служила «общепролетарскому делу». Опять же если того же Никиту Хрущёва в контексте действий по Крыму оценить по шкале русской «особости»? Передача Крыма вместе с городом Севастопо- 
лем под юрисдикцию Украины - это было предательством национальных интересов? Или действием на опережение - началом «самораспада» СССР? Или - атрибутом русской щедрой безмерности широты души: «Хочешь, возьми коня любого, возьми любой шатёр, возьми булат заветный, меч дедов!» - как в арии Кончака из оперы «Князь Игорь» А. П. Бородина. Русская доброта, переходящая в навязчивую ноздрёвщину (Ноздрёв - щедро-азартный, бесцеремонный, завиральный герой «Мёртвых душ» Гоголя). Отсюда и русский след в чужой коммунистической догме - заставить человека быть счастливым. И в то же время сами русские знают, что «насильно мил не будешь». Во всём крайностность: дойти до предела-пропасти, да ещё и заглянуть в неё.

Непатриотичность российских элит с лихвой компенсируется народной любовью к Отечеству с любыми правителями. «Безрелигиозное отщепенство от государства» болезнь элит со страданием народа. Бездумный перенос чужого интеллигенцией на русскую почву мутил национальное сознание.

«Рационалистический утопизм, стремление устроить жизнь по разуму, оторвав её от объективных начал истории, от органических основ общественного порядка, от животворящих святынь народного бытия» - привели, как полагает учёный П. И. Новгородцев, к революции-1917.

Рецепт исцеления русского общества по Достоевскому - перестать быть ничтожными подражателями (“стрюцкими”) европеизма, либерализма и социализма, и вернуться интеллигенции от космополитизма к осознанию себя частью общекорневой с народом системы. Чтоб обрести победное единство нации, надобно интеллигенции осознать, что «ей нельзя уже больше разъединяться и разрывать с народом своим». «Мы можем, пожалуй, проигрывать битвы, но все-таки останемся непобедимыми именно единением нашего духа народного и сознанием народным. ...если мы захотим, то нас нельзя заставить сделать то, чего мы не пожелаем, и что нет такой силы на всей земле».

Но России не удаётся подолгу сосредотачиваться на созидании государства. В 1913-м, когда она занимала первое место в мире по темпам роста промышленного производства и четвёртое по объёму его, разразившаяся Первая мировая война, перешедшая в большевистскую революцию, угробила саму Российскую Империю. Тем же деструктором в отношении уже СССР стал Беловежский сговор 1991-го по развалу Советского Союза. Власть была захвачена небольшой группой высокопоставленных чиновников. Компрадорско-власовский режим победившей «демократии» провозгласил независимость России от самой себя (не реализация ли это проекта «Россия без колоний»?) В результате вместо могучей Красной империи - сколок РФ. Над Кремлём взметнулся триколор - смахивающий расцветкой на голландско-«вла- 
совско-торгашеский» флаг Временного правительства, развалившего державу. Знамя Победы зачехлили, музейной мумией уложили (якобы «из-за хрупкости сатина») и в горизонтальном положении хранят. Рейстаг повержен - а стяг победителей пылится в музее! Ну а «копию» его «декоммунизировали» --- стерев с полотнища, а стало быть из памяти потомков, эмблематику оригинала: «совковые» серп и молот --- и употребляют этот новодел для парадных шествий.

Президент РФ воспринимается правящей элитой как топ-менеджер, «не мешающий» вольготно бизнесменить. Совокупность вотчин доминирующих кланов образует как бы государство в государстве: глубинно-олигархическое («deep state») vs. «Российская Федерация». Несмотря на коронавирусную пандемию и мировой системный кризис, прибыль прокремлевских богачей, согласно Bloomberg Billionaires Index, выросла за первый квартал 2021 года на 23,9 млрд. долларов. Кому война, а кому мать родна.

\section{Ельцинская}

Конституция-1993, написанная чуть ли не на коленке в ночь перед референдумом, узаконила беззаконие. Понятно: любые кардинальные перемены сложившегося «престолонаследия», включая честные демократические выборы, несли бы угрозу сформировавшемуся феодальному режиму. Посему истеблишмент предпочитает не подвергать свою власть риску перемен, держась стратегии «инериионного развития». Ельцинская си- стема руления страной с помощью «сдержек», «противовесов» и "рокировочек» остаётся путеводной для путинской «вертикали власти».

Владимир Путин, по оценке консервативным публицистом Михаилом Назаровым, «ничего не стал менять в сущности установившегося олигархического режима, лишь перевёл его из «Великой криминальной революции» (определение С. Говорухина) в Великодержавную криминальную стабилизацию». В этом ряду «достижений» власти компрадор-олигархата фигурирует межсобойно-договорная двойная «рокировочка»: Путин-Медведев и обратно. С «престолонаследием по сговору» люди свыклись: в марте 2021 позволили обнулить четыре предыдущих срока президентства, предоставив Владимиру Путину возможность ещё дважды баллотироваться на пост главы государства -- на выборах 2024/36.

По мнению политолога Валерия Коровина, прозападные элиты сейчас «за Россию не держатся, с удовольствием коллаборационируют, готовы предавать, что полностью коррелирует с ситуацией накануне Февральской революции 1917, когда главе государства стало не на кого опереться. Они являются носителями другой ментальности, Западу с ними легко работать, что было свойственно и предреволюционному периоду.» «С Россией кончено...И родину народ сам выволок на гноище, как падаль» - сказал о революционном 1917-м поэт Максимилиан Волошин. 
Несколько иначе в «лихие 90е» порешили и Красную империю СССР. Сперва изъяли краеугольный камень фундамента советского монолита - ст. 6-ю Конституции-1977 о партии как «руководящей и направляющей силе общества» что сразу обрушило «Союз нерушимый». Теперь, когда «красно-коричневые» группируются для реванша, то рулящие Россией вцепились в Путина чтоб их покровитель не бросил их на растерзание толпы. У либерал-имперца А. Б. Чубайса уход ВВП из Кремля и левый разворот державы вызывает истеричную реакцию: «Не дай Бог нам увидеть революцию в России. Она будет кроваво-красной... Объединение демократов на антипутинской основе неработоспособно.... Лозунг 'Долой полицейский режим Путина' звучит просто несерьёзно»-причитает он. Однако Запад на сей раз не прислушался к предостережениям со стороны своей креатуры. Интрига трансфера власти сохраняется. Но раз в международных отношениях попахивает Карибским кризисом-2, - почему бы не воспользоваться ситуацией и не придать путинизму назарбаевскую «руководящую и направляющую» вечность? Ведь и в Древнем Риме при крайней внешней опасности или внутренней смуте Консулами по решению Сената назначался диктатор. Пока далековато до ядерного апокалипсиса. Запад раздражён живучестью лузера, побеждённого в холодной войне, а побеждённый не признаёт себя таковым. (А отлита и медаль «За победу в холодной вой- не» / Cold War Victory Medal - ей награждён «почётный немец» Михаил Горбачёв.)

\section{Духовно-ицвилизационная оборона России; Атака менталитета как фактор усложнения конфликтов}

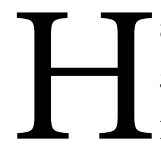

а оптимальном уровне РФ защищена, а на проактивном не совсем. В надёжней защите нуждаются как дальние ру-

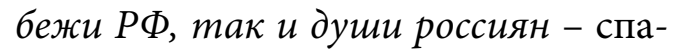
сения от разложения и депатриотизации. Только с осознанием своих национальных глубинных ценностей и целей, научившись действовать в соответствии со своими жизненными принципами - личность состоятельна как проактивная. Что касается проецирования силы и обеспечения безопасности на дальних рубежах, то «нам до этого довольно далеко» - утверждает аналитик Дмитрий Евстафьев. Предстоит освоить потенциал проактивного применения силы в экономических и политических интересах до возникновения прямой военной угрозы России. Ведь конфликты усложняются: уже атакуется сам менталитет.

C помощью информационно-организационного оружия духовный код атакуемого может быть трансформирован: подвергнут «самодезорганизации» и «самодезориентации» («очень вероятное» вмешательство РФ в американские президентские выборы или США организуют «цветные революции»). Военспец Д. Ловцов - знаток реф- 
лексивых технологий оргоружия утверждает, что с помощью разных воздействий на противника можно заставить его двигаться в угодном для другой стороны русле; направить политику противника в стратегический тупик; измотать его экономику неэффективными (непосильными) программами; затормозить развитие вооружения; исказить основы национальной культуры; создать среди интеллигенции «пятую колонну», всемерно поддерживающую, пропагандирующую и проводящую псевдореформы и т.п. В итоге в государстве создаётся обстановка внутриполитического хаоса, ведущая к снижению его экономической, политической, военной мощи и даже к гибели.

Проходя через сознание каждого члена общества, длительное массированное информационное и морально-психологическое воздействие разрушающего характера создаёт реальную угрозу существованию нации в результате трансформации её исторически сложившейся культуры, основных мировоззренческих и идеологических установок, т.е. смены внутренней оргсреды, определяющей жизнедеятельность государства и его вооружённых сил. Стабильное поддержание у противника стратегчческой иллюзии - условие победы в ментально-гибридной войне. В контексте гибридной войны важнейшее место занимают психологические операции. А как их проводить, если её объект, психология неприятеля, не совсем ясна, а её уязвимые места до конца не выявлены?
Псих-война от теоретических инсинуаций стала военной повседневностью. То ли фальшивка, то ли всё ещё тайна за семью печатями, но в газете «Советская Россия» от 20 февраля 1993 была заметка о «плане Даллеса». Вот что написал митрополит Санкт-Петербургский и Ладожский Иоанн (Снычев): «Посеяв в России хаос, - сказал в 1945 году американский генерал Аллен Даллес, руководитель политической разведки США в Европе, ставший впоследствии директором ЦРУ, - мы незаметно подменим их ценности на фальшивые и заставим их в эти фальшивые ценности верить. Как? Мы найдём своих единомышленников, своих помощников и союзников в самой России. Эпизод за эпизодом будет разыгрываться грандиозная по своему масштабу трагедия гибели самого непокорного на земле народа, окончательного, необратимого угасания его самосознания. Из литературы и искусства, например, мы постепенно вытравим их социальную сущность. Отучим художников, отобьём у них охоту заниматься изображением, исследованием тех процессов, которые происходят в глубине народных масс. Литература, театры, кино - все будет изображать и прославлять самые низменные человеческие чувства. Мы будем всячески поддерживать и поднимать так называемых творцов, которые станут насаждать и вдалбливать в человеческое сознание культ секса, насилия, садизма, предательства - словом, всякой безнравственности».

В нынешних инструктивных 
материалах по подрыву боеготовности противника изнутри фантастика стала былью. Основное зло - «рулящие» Россией как госкорпорацией - своей вотчиной. Компрадор-властелины РФ сознательно или невольно способствуют также ломке «дисциплинарной социализации» личности сограждан в РФ, после чего такой обработанный индивид не подчиняется более коллективным правилам. Французский философ Ж. Липовецки считает, что такое гедонизированное создание морально шатко, неустойчиво, безвольно, с ослабленной способностью к самоограничению и самоконтролю, с фрагментарным сознанием, в котором отсутствуют высокие идеалы, а воля требует гламура и потребительства, отдыха и развлечений. Такой субъект граждански и политически ничтожен, с атрофированным патриотизмом (без понятия что такое отдать свою жизнь за Родину).

Если стратег Карл фон Клаузевиц целью войны считает «заставить противника выполнять германскую волю», то сила духа россиян, воля к сопротивлению и победе ныне сильно подорваны. Военный теоретик Андрей Снесарев отмечал, что «эпицентр проблем познания войны: основной закон войны, закон главенства духовной стороны в явлениях боя». С поникшим боевым духом не победить. Дух - что огонь: без поддержки гаснет. Китайская стратагема достижения победы посредством разрушения духа как опоры сопротивления так и называется: «Вытаскивать хворост из-под оча- га». Что означает: когда противник слишком силен для открытой схватки, можно победить, разрушив его опору. Наличие несокрушимого духовного потенциала - залог победы.

По оценке социолога А. Янакова, духовный ресурс народа находит своё выражение в определённых ценностях, идеалах, идеях, теориях, концепциях, программах и лозунгах, общественных символах, взглядах, традициях, привычках, нравах, которые, как правило, базируются на общенациональных ценностях. «Упрочение духовно-цивилизационного арсенала усилило бы боеготовность как воинства, так и военной безопасности государства».

Если в классических войнах целью является уничтожение живой силы противника, в современных кибервойнах - уничтожение инфраструктуры противника, то целью новой войны является уничтожение самосознания, изменение ментальной - цивилизационной - основы общества противника. «Я бы назвал этот тип войны ментальным» - говорит советник Министра Обороны РФ Андрей Ильницкий. Причём последствия нформационно-гибридных атак на менталитет могут проявиться не сразу, а через поколение (когда ход эволюции сознания повернуть вспять уже будет невозможно). Трансформация Украины из «братской» в «бандеровскую» - пример методичного плохо контролируемого чуждого воздействия на смену духовного кода нации. Коррумпированные чиновники РФ годами попустительствовали антирос- 
сийскому нашпиговыванию «укров» для использования затем их как «сакральной жертвы» в чужой игре. А то что Россия во-время не спохватилась - не «санировала» трещинки в отношениях между Киевом и Москвой, а допустила разрыв исторической их общности -- так сама себя «выпорола». Кремль упустил: «хотел как лучше, а получилось как всегда». А когда уже вся самостийная затряслась в бандеровской пляске «кто не пляшет - тот москаль» - поздно было привязывать «самостийных» поддержкой режима Януковича: антироссийскость стала массовой. Российская же инициация Минских соглашений - мало что даёт РФ, зато спасла тогда после Дебальцева от неминуемого разгрома украинскую армию. И нескончаемость донбасской трагедии - больше из-за дивидендов жадного олигархата, поставляющих горючее для заправки танков «незалежной».

Если бы Путина не гнобил постоянно Запад, то начальники РФ давно бы сдали Донбасс «во исполнение минских соглашений». Что было бы срамом для переспектив Русского мира-аналогом операции 1945-го Keelhaul, когда англичане прикладами насильственно гнали казаков и белоэмигрантов под пули иль в ГУЛАГ во исполнение союзнических обязательств перед Сталиным. Однако тогда перед Иосифом Виссарионовичем сам Сэр Уинстон Леонард Спенсер Черчилль вытягивался во фрунт - пусть лишь почтения ради, "for respect" (не то что ныне: когда президент США Джо Байден кивком головы подтвердил, что его «коллега» из РФ - "murderer").

Как увязать необходимость поднятия боевого духа государствообразующей титульной нации РФ на фоне вырождения в РФ особенно русских и ужесточения наказательно-применительной практики антирусской 282-й статьи УКРФ? Русская воля (несгибаемый дух плюс пространство) с удалью молодецкой vs. «умеренность и аккуратность» скучной серости. Порождение вольницы безгранично раздольная русская песня, от которой сам философ Ницше «тронулся умом»: «Я променяю счастье всего Запада на русский песенный лад печали» - вырвалось у него. Так что русскому менталитету воли вольной чуточные послабления со стороны чиновного официоза - оскорбительны. Такие дарованные «свободы» - продуцируют лишь тварь дрожащую, вёрткую, а не бесстрашного богатыря Света Православного.

Сумятицу в формирование национальных приоритетов вносит тот факт, что в РФ не ведают какой тип государственности строят. Хотели бы - нечто «с человеческим лицом». Высшее чиновничество и без того запуталось в категориях «свой-чужой», помня лишь о мздоимстве и в каком из карманов куртки какой иностранный паспорт у них лежит. Они подменяют понятие «враг» беззубым эвфемизмом «партнёр». И лишь 13 апреля 2021 замглавы МИД Сергей Рябков, уловив дуновение новых эманаций Кремля, -- рискнул назвать США противником России. 
В своём послании Федеральному собранию Путин сравнил недругов России с героями рассказа Киплинга, отметив, что некоторые цепляют РФ без всяких причин и, как Табаки, подвывают, чтобы задобрить своего суверена. «Надеюсь, -- заявил Владимир Путин, -- что никому не придёт в голову перейти в отношении России так называемую красную черту. А где она будет проходить - это мы будем определять в каждом конкретном случае сами». Этот новый внешнеполитический манифест России произвёл эффект путинской мюнхенской речи.

Примерно в том же смысловом ключе глава русского внешнеполитического ведомства при Александре II князь А. М. Горчаков дал понять Западу, что Россия не отказывается от права голоса в европейских международных вопросах, но только собирается с силами для будущего. «La Russie ne boude pas elle se recueille» (Россия сосредотачивается). Эта фраза точно определяла занимаемое Россией политическое положение после Крымской войны. А три года спустя князь Горчаков заявил: «Россия выходит из того положения сдержанности, которое она считала для себя обязательным после Крымской войны». Так и Россия ныне декларативно вышла, словно из удавки договорняка с Западом в результате поражения в холодной войне, -- заявила о своих геостратегических намерениях. Опасно «медведя» загонять в угол. Глядишь - ещё с китайским тигром спарится назло надменным Евро-Анлантистам.

\section{Национально}

\section{ориентированная власть -} залог победы в ментально

\section{- гибридной войне}

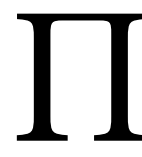
равящий класс плохо справляется с удовлетворением национально-патриотических запросов общества. Ещё далеко до нравственно здорового эффективного социального государства, которое только и сможет противостоять в «ментальной войне». «Но для этого в России, - пишет редактор «Русской идеи» Михаил Назаров, должна быть здоровая власть, заботящаяся о стране, а не о собственных «галерных» доходах». Иначе - поражение в мировой гибридной войне.

Трудно быть в РФ патриотом при госидеологии «газ со скидкой». Сей мировоззренческий остов мобилизатор народа на гражданственность, подвиг и труд, выброшен из Основного закона РФ, как «совковый» утиль. Мало того, 13-й статьёй Конституции запрещается установление какой-либо идеологии «в качестве государственной или обязательной». Оставили хотя бы в практических целях для управления обществом, недопущения хаотизации его и профилактики противоправных действий - учились бы у германских прагматиков: «Не имеет большого значения во что мы верим, главное - чтобы веровали. Народ без религии - как человек без дыхания». Не случайно фюрер пропаганды Геббельс признавался: «Моя партия - моя церковь». 
Тогда как у народа нет своей идеологии, номеклатура для своих нужд сохранила «некие сравнительно устойчивые и узнаваемые системы смыслов» -- опору на определённую ценностно-смысловую систему. Об этой коллизии философ Ольга Малинова пишет: «Очевиден потенциал "злоупотребления властью" для ослабления конкурентных шансов оппонентов, вплоть до ограничения идеологического плюрализма путём запрета на высказывание тех или иных идей в публичных средах. ... Властвующая элита не вправе использовать государственные инструменты принуждения, чтобы навязывать собственные представления как обязательные или исключать право на высказывание иных точек зрения». Принимаемые Госдумой законы, как утверждает оппозиция, нередко носят характер «оккупационных»: «практически все формы общественного протеста объявлены незаконными». Проект капитализма с человеческим лицом не получается: слишком жаден до сверхприбыли олигархат и скупа власть на достойное исполнение «социальных гарантий».

Спасительным представляется для России более органичный курс, духовной основой которого станет Русская идея как характеристика национального самосознания и культуры. Национальная русская идея религиозная, включающая промысел и предназначение. Она целостна и неизменна в основе. Её категории Духовность, Державность и Соборность (в Уваровской три- аде: Православие, Самодержавие и Народность) живо взаимосвязаны. «Рассечение указанного триединства, - пишет философ В. В. Лазарев, - созидавшегося по образцу и подобию триады Добра, Истины и Красоты или по образцу Святой Троицы (истолкование смысла триединства в которой заключено в Православном учении), разрознивание живой духовной целостности на отдельные элементы -превращало это единство в мертвенный конгломерат». Без смены парадигмы основного курса РФ, «национализации» самой логики мышления и усиления прорусской доминанты - страна утратит не только суверенитет, но и жизненные ресурсы для воспроизведения нации. Деградация и депопуляция идут полным ходом. Демографическую ситуацию в России сам путинский рупор Дмитрий Песков характеризует как «очень плохую».

От президента РФ для её национального возрождения ожидается подвиг: избавление пор Государства Российского от въевшегося в неё компрадорского олигархата. Тогда народ из «быдла» вновь обретёт облик творца истории и вдохновлённо отстоит свою Родину, у которой были и есть «только два союзника - её армия и флот». Необходима срочная радикальная коррекция государственного курса России на подлинный патриото-государственный. Не исключён путчевый сценарий смены власти: как в книге Кэтрин Белтон «Люди Путина: как КГБ захватил Россию, а затем взялся за Запад» (Catherine Belton, "Putin's 
People: How the KGB Took Back Russia and Then Took on the West"). И либертарианская «альтернатива» (не Михаил Ходорковский, так Алексей Навальный), судя по докладу А. Аслунда и Л. Гозмана "Russia after Putin: How to rebuild the state" («Pocсия после Путина: как восстановить государство»), не сдастся без боя. Общим консолидантом оппозиции могут стать некоторые тезисы этой программы, созвучные с лозунгами коммуно-патриотического электората, например, в намерении сменить режим «авторитарной клептократии»; или в смене правящей династии «ельцинской семьи», «узурпировавшей всю власть и большую часть богатства» России.

Руководству РФ надлежит перестать вести, как говорит патриот системный аналитик Сергей Михеев, «двойную игру - заигрывание с карликами». Утвердить верховенство закона. Политически разоружить привластный бизнес, настояв на «полной прозрачности конечной бенефициарной собственности всех предприятий, включая медиакомпании». Но есть ли надежда на столь кардинальную власть имущих?

Время не терпит. Политическая динамика в России заметно ускоряется. Если правящей «Единой России» будет грозить поражение, могут заменить президентскую форму правления на парламентскую (она по определению более прозрачна и демократична, а главное ответственность за развал страны станет «коллективной»), или на модель Госсовета с коллективным руководством (комбинация Политбюро ЦК КПСС и Госсовета КНР).

Какой лидер нужен народу на новом этапе развития? Политолог Сергей Михеев (партия «За правду» Захара Прилепина) на этот вопрос ответил развёрнуто: «Во внешней политике - более активный проект, который восстановит историческую справедливость... Во внутренней экономика как способ организации жизни людей, а не способ получения прибыли. Схема национальной культуры не подлежит экономическому регулированию. В морально-нравственном контексте - идеалы традиционных религий должны быть доминирующими в формировании информационного содержания, культурной политики. Человек, который будет двигать эти три ипостаси...Я таких людей не вижу».

А откуда таким «триадным» лидерам и взяться, если кандидатов-«чужаков» отфильтровывают на кадровых президентских программax, наглухо блокирующих попадание «не своих» на политический Олимп?! Поточное изготовление чиновников в заданных параметрах запроса рулящих РФ - «загашник» номенклатурных назначений. «Кадры решают всё» - говорил И. В. Сталин. Затруднение с выбором достойной «трёхаспектной» кандидатуры в президенты объяснимо, как сказано ранее, и извечным грехом интеллигенции: уж больно далеки они от народа. Певец народной 
монархии Иван Солоневич вменил этому сословию в вину его нежелание рассматривать себя «как слой, подчинённый основным линиям развития русской истории, а не как кооператив изобретателей, наперебой предлагающих русскому народу украденные у нерусской философии планеты полного переустройства и перевоспитания тысячелетней государственности».

Национально-приоритетными должны стать все сферы русской жизни, её политики, хозяйствования и культуры. И в международных отношениях без умения отстаивать интересы своей страны не может быть достойно-убедительной дипломатии. Переговорный процесс должен маневрировать не в рамках сиюминутных бизнес-выгод (как сейчас), а цивилизационно-национальных глобальных интересов. Поскольку международная договорная безопасность не работает в прежних режимах, надо отстраивать адекватную сложившимся обстоятельствам новую систему взаимосвязанности государств - с задействованием арсенала средств предотвращения как прямой военной, так и косвенных -экономико-политической и гибридно-этической агрессий.

«Война - это искусство обмана», сказал Сунь-дзы. Придётся исходить из данности, что принцип неприменения силы или угрозы силой как орудия национальной политики (Келлога-Бриана пакт 1928 г.) уступил место правы войны -- jus ad bellum). А былые наработки вирту- озного дипломатического искусства (включая практики «мистера нет» -Андрея Громыко) за длительным неприменением оных проржавели.

Внедряемая США стратегия «передовой обороны» применима и в «кибер-дипломатии» (мой термин - Е. В.). Это сближение с противником настолько близкое, насколько это возможно, чтобы увидеть, что он замышляет и планирует, и в ответ подготовиться или принять соответствующие меры. Актуализация «разведки боем». Дальновидная всеобъемлемость и в стратегическом планировании, и в оперативных разработках, помноженная на умение преследовать противника во время его маневрирования, с пониманием, как он развивается в качестве динамичного объекта. В этой связи важно учесть обновлённые спецификации дипломатии в эпоху глобализма и постмодерновой конфликтологии, выдвинутые новым главой ЦРУ Уильямом Джозефом Бёрнсом: «Конфликт великих держав требует тонкой дипломатии - нужно маневрировать в серой зоне между миром и войной, знать пределы возможного, выстраивать рычаги влияния, преследовать общие интересы там, где мы можем их обнаружить, - и жёстко и последовательно противостоять [России] там, где их нет». Разведка при Трампе заметно политизировалась. Именно непредвзятая объективная аналитика потомственного дипломата и «поседевшего на России» Бёрнса может быть услышана Байденом и адекватно воспринята Кремлём. «Новое мышление» (да 
не по Горбачёву, а скореe Realpolitik по Бисмарку) - без иллюзий и идеологических догм.

Манящ настрой на смягчение напряжённости в двусторонних отношениях. Игра с открытыми картами (пусть и со скрытыми козырями) уводит сознание оппонента от его «красных линий» во имя настройки на взаимовыгодный компромисс. Важен сам факт: «изгои» ввязаны в диалог. А дальше уже искусство торга многоуровневых соблазнов. Тем самым консолидируется Запад вокруг вытекающей из диалога общей пользы как с EC, так и в интересах США. Это проба «разведки боем» по инициации России и Китая посильно содействовать их интеграции в глобально-всецивилизационный проект единых ценностей и общего управления в постковидную эру. При нивелировании отдельно взятых национальных особостей и заменой их почвой для компромисса исчезнет понятие «враг», ведь воевать станет не с кем.

\section{Двусторонним}

диалогом уточняются границы компетенции каждой из сторон и их пределы для тактического отступления - не дальше дальних рубежей своих национальных приоритетов. В результате договорённости о согласовании и уточнении выстраиваются стратегические границы новой подвижной конфигурации. Это и есть текучая дипломатия, а не застывшая догматика «исполнения супружеских обязательств» давно нелюбящими друг друга. Время вялых геополитических инициатив и доктрин за- кончилась. Противостоянию систем во всеоружии призвано снизить напряжённость между противоборствующими сторонами. Стратегия плотного прессинга (так бы назвал я её) соответствует ситуации: Ныне и Запад, и Россия, и Китай не в лучшей кондиции. И каждый из геополитических актёров стремится не дать свой цейтнот перевести более сильным игрокам в цугцванг - в котором любой ход ведёт к ухудшению позиции. Ставки высоки: глобальная война, или возврат к статус-кво «ни войны, ни мира».

Скорей всего путинская заявка на «Мюнхен-2» лишь брутальная патриотическая риторика. Ведь в правящих кругах, пока у них не конфисковали капиталы за границей, будут царить совсем иные устремлённости: к реваншу прикремлевской «семьи» и неизменности хищнического компрадорско-олигархического курса.

Всё может быть. Ведь на серьёзные катаклизмы со стороны общества власти не реагируют адекватно: не считывают знаки и сигналы от народа, теряя и без того небольшую поддержку, легитимность. Нельзя власти, говорит эксперт Валерий Коровин, демонстрировать «высокомерную отчуждённость» и обращаться к народу только в ситуации, когда нужно провести выборы, либо когда начинаются волнения и массовые беспорядки. «Реакция власти носит крайне сиюминутный, раздражённый, нервозный характер и оказывает разовое влияние на ситуацию. Власть обращается к мас- 
сам как к некоему механическому множеству». Вот провели опрос, составили рейтинг, приняли решение, не слыша людей на самом деле, не вникая ни в нюансы, ни в детали. В итоге у государства потеряна точка опоры. Наблюдается двойной цугцванг: власти и оппозиции, Запада и России.

Стоило Путину заговорить о красной линии, как Патриарх Кирилл предостерёг власть от превращения в тиранию. Что день грядущий нам готовит?! Со стороны правящего истеблишмента продолжение слабой, трусливой невнятной политики спровоцирует взрыв народного негодования, а мобилизационный рывок поддержки -- увлечённость инициативой связанный с движением КрымНаш зачахнет на корню.

Нельзя долго испытывать терпение нации на позитивные перемены. Дождутся, видать, пока сам народ ни двинется штурмовать режим с песней «Вставай, страна огромная!» Тогда и прочертится сама собой красная линия дальних рубежей безопасности Родины. И пройдёт она уже не через Киев, а Варшаву. Скорей всего Путин своим выпадом лишь сообразно подходящему моменту запоздало ответил на заявление Джона Болтона в 1999 на совещании НАТО, указавшего тогда на красную линию от Балтики до Чёрного моря, с одной стороны которой расположен «цивилизованный мир, с другой - Россия».

Головой в РФ правит свита. Даже если бы и захотел Путин кардинально изменить коррумпированную олигархическую систему - ему бы помешало окружение, настроенное оппортунистически и коллаборационно. А главное - он сам, боясь красно-коричневого реванша СССР-2 теоретически пуще западной экспансии боится российской народно-патриотической системной оппозиции. Поэтому он априори Западу ближе, чем его изображают. Поэтому Западу и следовало бы скорректировать новый курс по отношению к Кремлю: не гнобить президента РФ, а продлевать его правление страной, методом умеренных уступок со стороны Запада и удержания РФ в своей орбите.

Д-р Евгений Александрович Вертлиб/ Президент Международного института стратегических оценок и управления конфликтами (МИСОУК-Франция); ответственный редактор отдела прогнозирования политики Запада «Славянской Европь» (Мюнхен); экзекьютив член Инищиативы «Лиссабон-Владивосток» (Париж) 